\title{
Review
}

\section{Harnessing Synergistic Biostimulatory Processes: A Plausible Approach for Enhanced Crop Growth and Resilience in Organic Farming}

\author{
Md. Nasir Hossain Sani ${ }^{1, *(1)}$ and Jean W. H. Yong ${ }^{2, *(\mathbb{D})}$ \\ 1 School of Natural Sciences, Bangor University, Bangor LL57 2DG, UK \\ 2 Department of Biosystems and Technology, Swedish University of Agricultural Sciences, \\ 23456 Alnarp, Sweden \\ * Correspondence: nsanisau@gmail.com (M.N.H.S.); jean.yong@slu.se (J.W.H.Y.)
}

check for updates

Citation: Sani, M.N.H.; Yong, J.W.H. Harnessing Synergistic

Biostimulatory Processes: A Plausible Approach for Enhanced Crop Growth and Resilience in Organic Farming. Biology 2022, 11, 41. https:// doi.org/10.3390/biology11010041

Academic Editor: James White

Received: 8 December 2021

Accepted: 26 December 2021

Published: 28 December 2021

Publisher's Note: MDPI stays neutral with regard to jurisdictional claims in published maps and institutional affiliations.

Copyright: (C) 2021 by the authors. Licensee MDPI, Basel, Switzerland. This article is an open access article distributed under the terms and conditions of the Creative Commons Attribution (CC BY) license (https:// creativecommons.org/licenses/by/ $4.0 /)$.
Simple Summary: Demand for organically grown crops has risen globally due to its healthier and safer food products. From a sustainability perspective, organic farming offers an eco-friendly cultivation system that minimizes agrochemicals and producing food with little or no environmental footprint. However, organic agriculture's biggest drawback is the generally lower and variable yield in contrast to conventional farming. Compatible with organic farming, the selective use of biostimulants can close the apparent yield gap between organic and conventional cultivation systems. A biostimulant is defined as natural microorganisms (bacteria, fungi) or biologically active substances that are able to improve plant growth and yield through several processes. Biostimulants are derived from a range of natural resources including organic materials (composts, seaweeds), manures (earthworms, fish, insects) and extracts derived from microbes, plant, insect or animal origin. The current trend is indicative that a mixture of biostimulants is generally delivering better growth, yield and quality rather than applying biostimulant individually. When used correctly, biostimulants are known to help plants cope with stressful situations like drought, salinity, extreme temperatures and even certain diseases. More research is needed to understand the different biostimulants, key components, and also to adjust the formulations to improve their reliability in the field.

\begin{abstract}
Demand for organically grown food crops is rising substantially annually owing to their contributions to human health. However, organic farm production is still generally lower compared to conventional farming. Nutrient availability, content consistency, uptake, assimilation, and crop responses to various stresses were reported as critical yield-limiting factors in many organic farming systems. In recent years, plant biostimulants (BSs) have gained much interest from researchers and growers, and with the objective of integrating these products to enhance nutrient use efficiency (NUE), crop performance, and delivering better stress resilience in organic-related farming. This review gave an overview of direct and indirect mechanisms of microbial and non-microbial BSs in enhancing plant nutrient uptake, physiological status, productivity, resilience to various stressors, and soil-microbe-plant interactions. BSs offer a promising, innovative and sustainable strategy to supplement and replace agrochemicals in the near future. With greater mechanistic clarity, designing purposeful combinations of microbial and non-microbial BSs that would interact synergistically and deliver desired outcomes in terms of acceptable yield and high-quality products sustainably will be pivotal. Understanding these mechanisms will improve the next generation of novel and well-characterized BSs, combining microbial and non-microbial BSs strategically with specific desired synergistic bio-stimulatory action, to deliver enhanced plant growth, yield, quality, and resilience consistently in organic-related cultivation.
\end{abstract}

Keywords: plant biostimulants; synergistic effect; nutrient use efficiency; abiotic stress; crop resilience; organic farming; phytohormones; microbes 


\section{Introduction}

The pressing concern of global food security combined with projections of global population increase and climate change poses a major threat to agriculture in terms of reliability, sustainability, maximizing productivity while minimizing the agro-ecosystems environmental impact. The current global population is expected to rise from approximately 7.5 billion to over 9.7 billion by 2050 [1]. Consequently, global requirement for food crops was projected to rise by at least $60 \%$ by 2050 [2]. The green revolution has increased agricultural productivity by intensifying food production through the extensive use of chemical fertilizers, agrochemicals, and modified crop varieties. However, in many cases, commercialization of these practices has a substantial impact on soil health, inevitably leading to hazardous environmental consequences. The prolonged and extensive usage of agrochemicals and fertilizer has inevitably led to soil degradation, soil acidification, depletion of essential soil nutrients, groundwater contamination, eutrophication of waterways, and greenhouse gas emissions [3,4]. Recent studies reported that approximately $1 \%$ of chemical pesticides actually reach their target sites, and remaining amount resided in the environment $[5,6]$. Besides, loss of beneficial microbial populations from soil is one of the serious long-term impacts of agrochemicals in the soil ecosystem $[7,8]$. In this context, organic farming, which restricts the use of agrochemicals, has drawn tremendous consumer attention and scientific interest.

Over the last decades, consumers' interest in organically grown crops has risen worldwide due to its healthier and safer products [9-11]. Furthermore, organic farming offers an eco-friendly production system that minimizes off-farm inputs and minimal damage to the ecosystems $[9,12]$. However, organic agriculture's biggest drawback is the generally lower yield in contrast to intensive farming $[9,13]$. Several meta-analyses reported $8-25 \%$ lower yield in organic farming than intensive farming [13-15]. Therefore, more land is required to produce the same yield return, which in many instances contribute to greater land-use requirements (e.g., deforestation) and, consequently, outweigh the environmental benefits of organic farming practices $[9,16]$. The major yield-limiting factor in organic farming is associated with nutrient bioavailability, uptake, and assimilation owing to slow and/or inconsistent release of nutrients from various organic inputs [11,17]. Furthermore, biotic pressures (both fungal and bacterial diseases) were reported to cause substantial yield reduction in some organic production systems [18,19]. Apart from this, the rapidly changing climate poses environmental constraints, including drought, temperature, and salinity stresses [20,21]. Genetically modified (GM) crops remain a feasible option to overcome such limitations. However, research and regulations required to produce resistant varieties through traditional breeding approaches would take decades to reach the market place with formal approvals [22]. Therefore, to address these contemporary challenges in an environment-friendly, practical, and sustainable way, organic farming practices seek innovative solutions focusing on nutrient use efficiency (NUE), consistency in nutrient availability, abiotic stress tolerance, crop yield, and quality $[9,23,24]$.

A plausible, innovative and organic farming compatible technology would be the use of plant biostimulants (BSs) that have recently gained much interest globally [21,25-29]. According to du Jardin [30], BSs are naturally occurring compounds that stimulate plant physiological and molecular processes and thereby modulating crop yield and quality. However, there is no legal framework globally for defining BSs from a regulatory perspective [31,32]. Nonetheless, the global BSs market continues to grow rapidly, surpassing $€ 2.7$ billion by 2022, propelled by many governments' increasing focus on improving sustainability while reducing the environmental footprint of food production [33]. Moreover, the estimated demand for organic food products is over US $\$ 300$ billion by 2022, with simultaneous increase in organic farmland of 75 million hectares by 2020 [33].

In recent years, advancement in biochemical, genomic, and transcriptomic tools significantly contributed to unveiling the mode of actions of BSs [27,34-37]. This advancement has opened the doors for many BSs related industries to look for more effective and reliable formulations by blending microbial BSs with non-microbial BSs. However, many of these 
approaches were implemented without having proper scientific evaluation. Recent literature reported that the purposeful combinations of microbial and non-microbial BSs would interact synergistically and enhance growth and yield over a single application $[24,32,33]$. Designing target-specific BSs formulations would be pivotal for increasing NUE, consistency in nutrient availability, crop growth, and resilience in supporting a renaissance in organic farming. However, little is known about the interactive effects between microbial and non-microbial BSs, their ecological effects on rhizosphere microbes, rhizosphere, and plant metabolic dynamics. This review examined bio-stimulatory actions/mechanisms, interactive effects of microbial and non-microbial BSs affecting growth, and resilience to environmental stresses. It also discussed the scientific progress made in microbial and non-microbial BSs formulations and their performance in various fields and greenhouse experiments. The review also identified issues hindering improvements in crop yield and resilience as the world moves towards meeting the challenges of sustainable farming.

\section{Microbial and Non-Microbial Biostimulants: Action/Mechanisms and Biostimulatory Effects on Plants}

Bio-based products such as organic BSs render a sustainable, effective technology for enhancing NUE and ensuring a stable yield of agricultural and horticultural crops under optimal and sub-optimal conditions [24,26,32,34-38]. Non-microbial organic BSs include humic substances (HSs), protein hydrolysates (PHs), and seaweed extracts (SWEs). Besides, bacterial-based BSs, including diverse species of PGPRs (Azotobacter, Azospirillum, and Rhizobium spp.) and fungal-based BSs (Trichoderma spp., mycorrhizal fungi) have been promoted as promising microbial BSs for enhanced crop productivity and stress tolerance in numerous crops $[29,38-40]$. Based on scientific literature, we collated the different effects of BS application on various agronomic, physiological, biochemical, and molecular aspects of plant growth, productivity, quality, and resilience (Figure 1). Apart from the bio-stimulatory effects of BSs on crops and other species, it was important to shed more light on the key mechanisms of non-microbial BSs (Figure 3) and microbial BSs (Figure 2) involved in regulating physiological and other metabolic processes, leading to better NUE, growth and resilience.

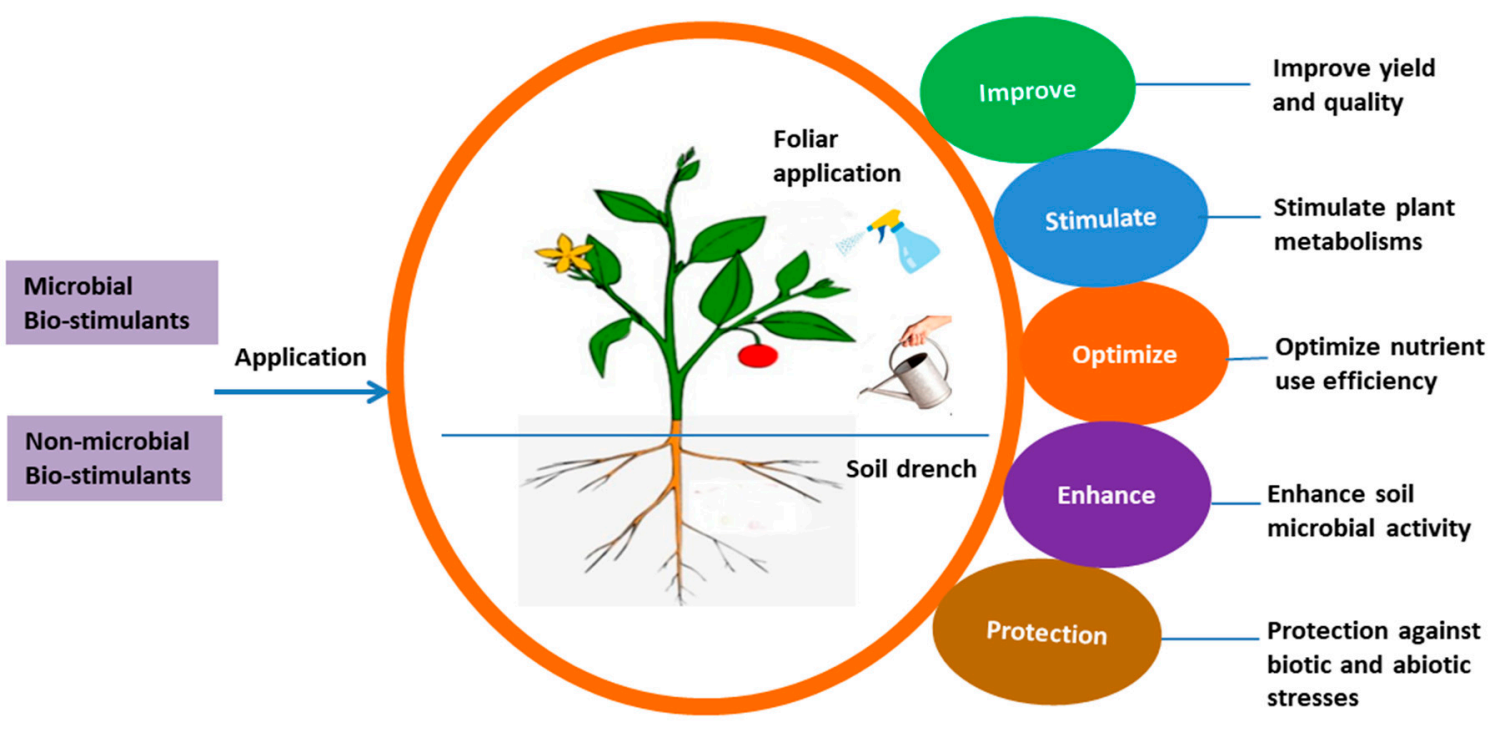

Figure 1. Bio-stimulatory effect of microbial and non-microbial biostimulants on different aspects of plant growth and productivity; Adapted from [40]. 


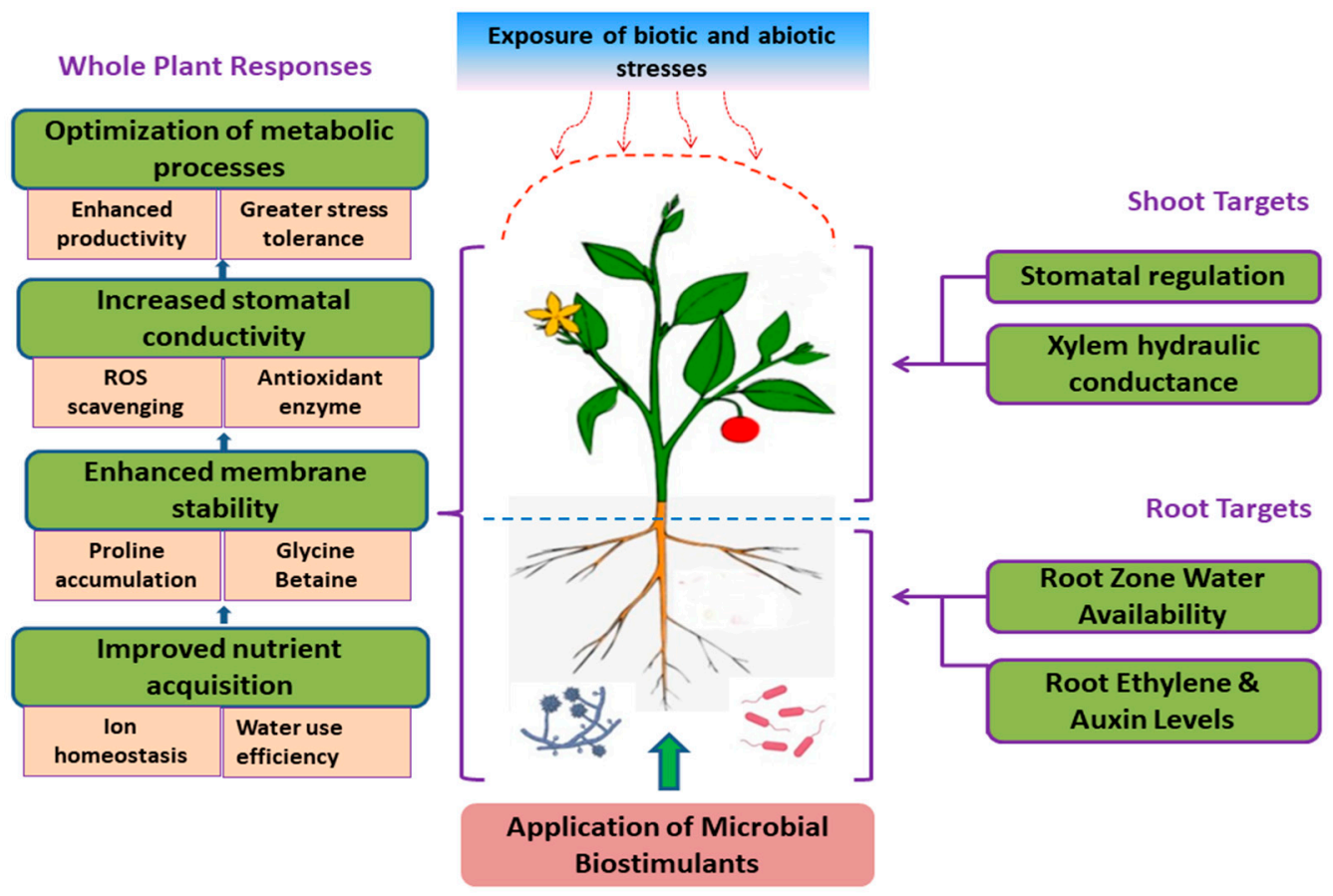

Figure 2. Key plausible bio-stimulatory mechanisms targeted by microbial biostimulants upon interaction with plants and their growing environment.

\subsection{Non-Microbial Plant Biostimulants}

\subsubsection{Humic Substances}

Humic substances (HSs) are natural soil organic substances derived from plant, animal, microbial decomposition, and the metabolic activity of soil microbes. These heterogeneous compounds exhibit complex dynamics with soil microbes that are influenced by plant roots and their exudates. The interactivity of HSs, plant roots, and rhizosphere microbes combined generally to promote plant growth and yield. In fact, HSs are well recognized for their long-term contribution to soil fertility through enhanced physical, chemical, and biological attributes. The most widely reported bio-stimulatory action of HSs is the enhanced macroand micro-nutrient uptake through increased cation exchange capacity of soil, known commonly as the HS-facilitated root nutrition. The stimulation of plasma membrane $\mathrm{H}+$ ATPases transformed free energy produced by ATP hydrolysis into a transmembrane electrochemical potential that is used for importing nitrate and other nutrients [41,42]. HSs are known to interact with calcium-phosphate precipitation and thereby increasing phosphorus solubility for plant uptake [42,43]. Additionally, HSs were reported to regulate reactive oxygen species (ROS) concentration and superoxide dismutase (SOD) genes in cytosol, promoting cell growth and differentiation [44]. The biostimulatory actions of HSs were found to be effective in increasing root uptake of sulphate as well as gene expression of primary sulphate transporters in roots [45]. Interestingly, HSs were involved in triggering the signaling pathways mediated by auxin and nitric oxide, along with up-regulation of numerous auxin-regulated genes in roots [42,46]. Apart from this, HSs could enhance key enzyme activity due to their higher molecular masses that could modulate stress responses $[47,48]$. HSs were able to reduce hydrogen peroxide, and lipid peroxidation, thereby increasing proline content and favoring a stress-responsive microbial community in rhizosphere, especially against salinity and drought $[49,50]$.

\subsubsection{Protein Hydrolysates}

Protein hydrolysates (PHs) are a complex group of compounds derived from the chemical and enzymatic protein hydrolysis of agro-industrial and household byproducts of plant and animal origins [25,34,51]. Animal sourced PHs include leather byproducts, fish 
byproducts, and chicken feathers, whereas plant origin PHs include vegetable byproducts, legume seeds, alfalfa hay, etc. [52]. Recently, PHs obtained from fish-waste and other aquaculture byproducts have become popular in various communities and industries due to the eco-friendly approach to waste disposal and contributions to circular bioeconomy [53]. According to Colla and co-workers [54], PHs represented a vital category of organic nonmicrobial BSs with a mixture of active compounds such as amino acids, oligopeptides, polypeptides, etc. These compounds could act directly or indirectly as signaling molecules triggering numerous physiological and molecular processes in plants; thus enhancing growth, and mitigating the adverse effects of abiotic stressors on crops [24,35,36,54-56]. PHs stimulate carbon and nitrogen metabolisms, activating key enzymes involved in $\mathrm{N}$ uptake and assimilation [30,55]. Interestingly, some phytohormones were found in certain type of PHs; while other PHs showed hormone-like (mainly auxin related) activities in bioassays [24,54-56]. Furthermore, PHs contained bioactive peptides, that were reported to stimulate hormonal activities $[24,55,56]$. Several greenhouse and open-field experiments demonstrated that commercial PHs were able to elicit hormone-like actions (auxin and gibberellins) and fostered favourable root and shoot development leading to better crop productivity [35]. In addition, PHs were reported to modulate root architecture especially root hair development and improving nutrient uptake [54].

\subsubsection{Seaweed Extracts}

Seaweed extracts (SWEs), predominantly brown seaweed extracts, are widely used BSs for growth promotion and mitigating abiotic stress such as salinity, drought, and extreme temperatures in many agricultural and horticultural crops. The commercial SWEs from brown seaweed contain a complex mixture of polysaccharides, fatty acids, phytohormones (auxins, cytokinins, gibberellins, abscisic acid, and brassinosteroids), vitamins, mineral nutrients, and a diverse range of organic components [57-59]. SWEs also contain various osmolytes such as betaines that play a crucial role in osmotic and temperature stress tolerance in plants $[60,61]$. Researchers are working actively on discovering the diversity of bioactive compounds in SWEs and elucidating their bio-stimulatory actions/mechanisms in plants [57-61]. Using advanced analytical tools (metabolomics and transcriptomics approach), researchers discovered alga-specific polysaccharides, betaines, polyamines, phenolic compounds, and phytohormones; these compounds could regulate several gene expression and signaling pathways that are responsible for many observed effects on plants [58-61]. For instance, SWEs were reported to regulate the nitrate transporter gene "NRT1.1." which has a significant role in N uptake and assimilation [62]. Furthermore, Khan and co-workers [63] reported that Ascophyllum nodosum SWEs activated the nodC bacterial gene and triggered bacteria-plant signaling by mimicking the effect of a flavonoid, luteolin. The triggering of flavonoid production by SWEs plays a substantial role in regulating plant development and responses to UV light and other environmental stresses, although the precise mechanism remains unclear [64]. In addition, the constituents of SWEs were able to induce root colonization of beneficial fungi in rhizosphere [65]. A recent molecular study highlighted the possible mechanisms of SWEs in regulating plant growth and development through hormonal homeostasis, biosynthesis of new transporters for nutrient uptake and assimilation, stimulating photosynthesis, and stress tolerance [66]. Moreover, SWEs were able to promote antioxidant stimulation whilst reducing lipid peroxidation under abiotic stress and contributing to the scavenging of reactive oxygen species (ROS) $[58,59,61]$.

\subsubsection{Bioconversion Compost-Derived Biostimulants}

Apart from the well-defined categories of BSs, bioconversion of organic by-products that exhibit bio-stimulatory activity could also be classified as a new sub-category within existing ones, as well as creating additional avenues for waste and by-product management $[9,27,28,67-70]$. Multiple studies have demonstrated that bioconversion composts, such as earthworms (vermicompost) and larvae-based (e.g., mealworms, black soldier fly) bioconversion compost, produced a substantial number of bioactive compounds that have 
a wide range of beneficial impacts on plant growth, soil attributes, and alleviation of abiotic stresses $[28,68,70,71]$. The bio-stimulatory activity of vermicompost is due to a combination of plant hormones, cytokinins, auxins, abscisic acid, gibberellins, brassinosteroids, and other beneficial compounds yet-to-be-identified. For example, numerous cytokinin types have been identified and quantified in vermicompost using advanced analytical technique of mass spectrometry [28,72]. These include zeatin (Z) and isopentenyladenine (iP) classes of cytokinins, which serve as positive phytohormonal signals and guide the plants to advance through key cell cycle checkpoints culminating in increased cell proliferation and growth [28,73-75]. Earthworms' faeces (vermicompost) have been shown to contain iP-type cytokinins due to the presence of gut microbiota in the digestive system, which are antecedents of Z-type cytokinins [28,76]. Interestingly, coconut water was reported to contain a significant amount of Z-type cytokinins and other phytohormones, which have the potential to regulate plant growth as BSs [77-79]. Research has specifically linked cytokinins and auxins found in coconut water to a variety of beneficial effects, including plant growth biostimulation, through the regulatory role in plant cell cycle and signaling pathways via several critical molecular checkpoints $[73,74,80]$. In light of these findings, it was suggested that plants could obtain additional cytokinins in addition to those produced endogenously by directly enriching the soil with a phytohormone-based BSs product. Furthermore, other phytohormones, such as gibberellins, auxins, and brassinosteroids, are anticipated to boost growth-related physiological effects when vermicompost is applied to the soil matrix $[28,70,71,81]$. The presence of humic and fulvic acids in vermicompost boosted nutrient absorption and activated membrane-associated signal transduction cascades that govern plant growth and development [70,82]. The biostimulatory action of betaines derived from seaweed extracts was also well-established in scientific literature [59,60]. Recently, Huang and co-workers [83] discovered the existence of several betaines in vermicompost and larval bioconversion compost. Betaines have been demonstrated in numerous trials to play a critical role in stabilizing enzyme and protein structure, improving the protection of lipids and membranes and enhancing plants' resilience to various stressors [84,85].

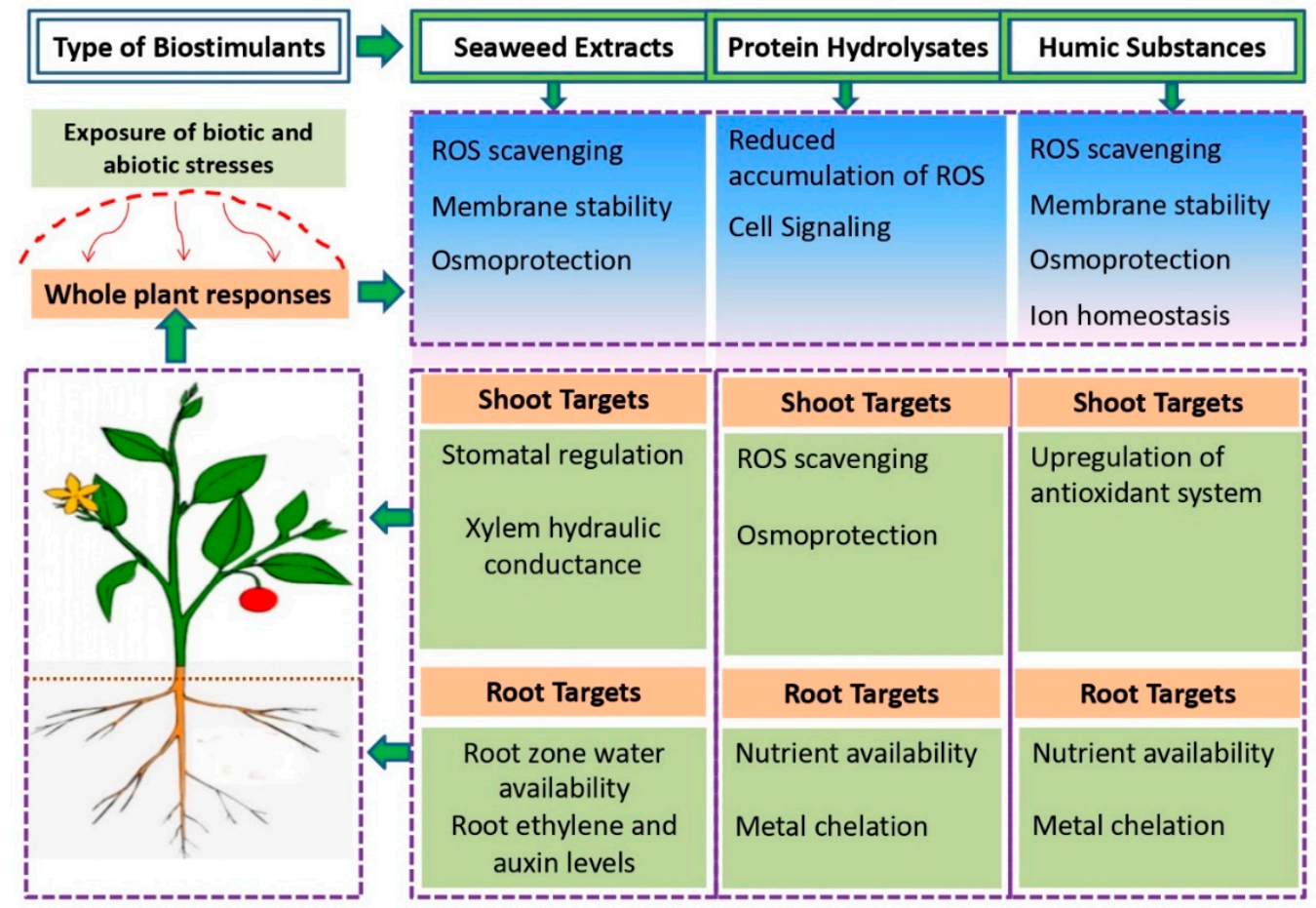

Figure 3. Key bio-stimulatory mechanisms targeted by non-microbial biostimulants upon interaction with plants and their growing environment; adapted from [86,87]. 


\subsection{Microbial Plant Biostimulants}

\subsubsection{Fungal-Based Microbial Biostimulants}

During the evolution of terrestrial plants, plants and fungi have co-evolved together; fungi interact with plant roots in numerous ways, ranging from mutualistic to parasitic $[88,89]$. Several scientific studies demonstrated that the parasitism-mutualism continuum is beneficial for maintaining ecosystem balance and increasing crop growth and productivity [29,90-93]. According to leading BSs researchers [30,34,51], the biostimulants' classification includes fungal-based products used on plants for promoting nutrient uptake efficiency, stress tolerance, crop performance, and product quality. The widely known fungal BSs are Trichoderma spp. and various mycorrhizal fungi; well known to increase nutrient uptake and plant growth in an environmentally-friendly way [24,56,94-97]. Commercially, Trichoderma spp. have gained much interest as "effective" microbial BSs due to their multifunctional role in mitigating biotic and abiotic stresses on crops [24,94,95]. Several research groups reported that Trichoderma species improved root to shoot signaling by stimulating the biosynthesis of several hormones; these included enhancing nutrient solubility, uptake, assimilation, and leading to higher crop productivity [24,56,65,94,95]. Arbuscular mycorrhizal fungi (AMF), another commonly used microbial BSs, form interesting symbiotic associations with more than $90 \%$ of plant species and economically important crops $[88,89,94,95]$. Generally, AMF provide widespread benefits in sustainable agriculture by improving the nutrient exploration in soil matrices, nutrient uptake and maintaining ion homeostasis under normal and stressful conditions. Although beneficial fungi and their products are widely used as BSs to enhance growth, productivity, and resilience to environmental stresses $[65,88,94-97]$, the complexity in their interactions with other soil microbes do make it difficult to determine their host-specific bio-stimulatory functions, interactions and nutrient dynamics within any agro-ecosystems [16,29,56,94-97].

\subsubsection{Bacterial-Based Microbial Biostimulants}

Bacterial-based BSs are formulations of microbial-derived compounds and diverse groups of plant growth-promoting Rhizobacteria (PGPR) and other beneficial bacteria (e.g., Actinomycetes) that promote root development, growth, and stress tolerance $[2,29,39,98]$. The bacterial taxa commonly used as microbial BSs include Acetobacter, Agrobacterium, Azospirillum, Azotobacter, Bacillus, Burkholderia, Enterobacter, Frankia, Pseudomonas, Rhizobia, Serratia, and Streptomyces [39,75,98-104]. Applications of microbial BSs were reported to alter several metabolic processes, influence ion homeostasis, enhance water holding capacity, and strengthen antioxidant defense mechanisms, thus delivering better plant growth and resilience $[29,51,98,99]$. The bio-stimulatory effect of bacterial-based microbial BSs under both normal and stress conditions could be attributed to various direct and indirect actions/mechanisms: (i) enhancing nutrient availability in soil, plant uptake and assimilation; (ii) modulation of root system architecture; (iii) improving water relations and photosynthetic efficiency; (iv) strengthening the antioxidant defense system; (v) production and regulation of phytohormones (auxins, ABA, cytokinins, ethylene, and gibberellins, etc.); (vi) promoting nutrient transporters (NRT1.1, NRT2, NAR2.2, AMT, Pht1, and PT2-1); and (vii) modulation of soil microbiome through enzymes and organic compounds $[24,39,75,98-105]$.

\section{Implications of Biostimulants for Enhancing Plant Nutrition in Organic Farming}

\subsection{Soil Nutrient Availability}

Organically grown crops are often subjected to nutrient shortages attributed to low soil nutrient levels or to poor nutrient solubility within rhizosphere. Increasing nutrient availability and improving utilization efficiency, especially $\mathrm{N}$ and $\mathrm{P}$, are critical for growers operating in this "low-input" cultivation system. The use of bioactive natural substances and inoculants, commonly defined as BSs, would be a valuable method to increase NUE in organic agriculture $[9,11,24,39,75,94-96]$. Operating within any organic production system ("low input" system), the strategic usage of selected BSs will improve 
nutrient availability by enhancing cation exchange capacity (CEC), thereby increasing the solubility of nutrients in soil for plants' uptake [42,55,82]. HSs have been reported to enhance soil physico-chemical attributes, consequently increasing essential soil nutrient availability $[42,55]$. Furthermore, HSs increase CEC and buffer soil $\mathrm{pH}$, which facilitated certain nutrients to become available [42,82]. HSs could also form soluble HSs complexes with trace elements that were identified as a sustainable strategy to prevent micronutrient leaching, thus enhancing their availability for plant uptake [82,106,107]. Several research documented that HSs activated the H+-ATPase plasma-membrane, thereby increasing radical $\mathrm{H}+$ extrusion and reducing root surface $\mathrm{pH}$, which facilitated increased soil nutrient availability for enhanced absorption and translocation [42,82]. PHs also improved soil nutrient availability by forming complexes and chelates between peptides and micronutrients, thus facilitating root-zone nutrient availability $[30,52,54,55]$. Moreover, $\mathrm{PHs}$ provide microbes with amino acids and peptides, thus enhancing substrate availability for microbes, soil respiration and promoting microbial activity, leading ultimately to better nutrient availability [108]. SWEs are another group of organic BSs containing alginates that were reported to be effective soil-conditioners and able to form high molecular mass polymers via metal chelation $[109,110]$. Furthermore, it was reported that these cross-linked polymeric networks would enhance the soil's water-holding capacity, promoting root growth and microbial activity and thereby improving nutrient availability in soil [110]. Apart from the non-microbial BSs, microbial BSs such as PGPR were able to promote plant growth through improving nutrient availability, especially for N, P, and Fe [98-100]. In addition, through the production of organic acids, PGPR could enhance solubility of phosphates in both organic and conventional systems [98,111]. Fungal-based BSs Trichoderma species were able to enhance iron solubility by producing siderophores, thus enhancing plant nutrient uptake $[94,95,98,112]$. Similarly, AMF could develop extensive hyphal networks to enlarge the surface area for nutrient exploration and uptake and producing organic substances that could solubilize P $[95,96,113,114]$. Moreover, AMF indirectly increased nutrient availability by improving soil aggregate stability, enhancing cation retention, especially $\mathrm{Ca}^{2+}$ and $\mathrm{Mg}^{2+}$, and improving the nitrification process [115].

\subsection{Plant Nutrient Uptake}

Plant nutrient uptake is influenced by a range of factors, including plant species, physiological status, environmental conditions, root growth, and root-associated microorganisms $[98,107,116]$. In a typical organic farming system, root growth plays a vital role in nutrient acquisition where soil nutrient is usually available at comparatively lower concentrations. In this context, the extensive and vigorous root growth, with optimal root architecture is imperative for ensuring sufficient nutrient uptake to meet crop nutrient demand in this "low-input" farming system. Several studies demonstrated that BSs such as HSs, PHs, and SWEs could foster better root growth and development, thereby facilitating the exploration of more soil matrices for plant nutrient uptake [24,117]. BSs are effective not only for stimulating root growth but can also increase the amount of nutrients absorbed by plants. For instance, studies have demonstrated that HSs not only increased the bioavailability of micronutrients under nutrient-limited conditions but also able to enhance root's capacity to absorb micronutrients from soil solution $[106,107,118]$. According to Colla and co-workers [52], PHs stimulated root growth in many crops such as tomato, lettuce, corn, etc. Similarly, for another group of commonly used BSs, the SWEs were effective in stimulating root growth in cuttings [119]. Furthermore, it was also reported that polysaccharide-enriched SWEs promoted stronger root growth-promoting action through several processes: triggering of signaling molecules, changes in endogenous phytohormone metabolism, and up-regulation of selected metabolic genes [120]. Interestingly, some BSs can stimulate specific enzyme activity and promote micronutrient uptake. For instance, PHs enhanced the Fe (III)-chelate reductase activity in both roots and leaves, leading to Fe's uptake and assimilation under Fe deficient conditions [121]. 
Several researchers have reported that microbial BSs such as AMF and Trichoderma spp. stimulated root growth by producing auxin-like compounds, which promoted root formation [94-97]. A recent meta-analysis of 52 published PGPR articles reported that PGPR generally increased root biomass by $35 \%$ and $43 \%$ under well-irrigated and water deficit conditions, respectively [122]. The increased root growth triggered by AMF and PGPR allows plants to explore more soil matrices, thus strengthening plants' capacity to cope with possible low nutrient and soil water availability situations. Moreover, HSs were able to upregulate several nutrient transporter genes such as the nitrate transporters (BnNRT1.1 and BnNRT2.1) and sulfate transporters (BnSultr1.1 and BnSultr1.2), thereby increasing nitrogen and sulfate uptake by plants [45]. Apart from non-microbial BSs, microbial BSs such as AMF and PGPR were reported to upregulate the nitrate transporter gene (NRT1.1, NRT2, and NAR2.2) expressions and subsequently increase the nitrogen uptake [105].

\subsection{Plant Nutrient Assimilation}

BSs can promote the assimilation of nutrients (for example, nitrate, ammonium, phosphate, and sulfate) directly through inducing gene expression of plant metabolism enzymes; and indirectly by increasing nutrient absorption and transport. Jannin and co-workers [45] conducted a microarray analysis of 31,561 genes. They demonstrated that 300 genes were expressed after three days following HSs' application, whereas the numbers were reduced to 102 genes after 30 days. Among them, $80 \%$ of the genes were related to sulfate metabolism and these were upregulated by HSs. The bio-stimulatory actions of PHs were also reported to stimulate enzymatic activity of carbon metabolism (malate dehydrogenase, citrate synthase, etc.) and as well as assimilation of nitrate (nitrate reductase, glutamine synthetase, aspartate aminotransferase, etc.) [123]. A similar observation was also reported by Ertani and co-workers [124], who found higher nitrate reductase and glutamine synthetase activity after receiving PHs treatment; leading to higher nitrate assimilation in roots and leaves of corn seedlings. Foliar application of SWEs were reported to enhance foliar nitrate reductase and trans-zeatin riboside (a cytokinin) levels in bentgrass [125]. A recent study reported that SWEs (extracts with some modifications) of A.nodosum upregulated the nitrate transporters' (NRT1.1, NRT2.1, NRT1.5) gene expression and some other associated $\mathrm{N}$ assimilation enzymes in spring barley roots, thereby enhancing NUE; barley yield was maintained despite using 27\% less $\mathrm{N}$ fertilizer under field conditions [62,126]. Interestingly, the stimulatory action of SWEs was observed to be more pronounced when plants were grown at lower nitrate levels, which implied that SWEs application might be a suitable strategy to enhance nutrient assimilation under nutrient-limited conditions commonly encountered in many organic farming scenarios [127]. Apart from the normal conditions, AMF and PGPR microbial BSs were reported to increase nitrate reductase activity in lettuce under moderate drought stress conditions [128]. Therefore, BSs appeared to be more effective for plants encountering sub-optimal conditions such as nutrient deficiency and adverse climatic conditions.

\section{Implications of Biostimulants for Enhancing Crop Physiology, Productivity, and Quality}

Plant growth and yield are influenced by a variety of complex genetic, biochemical, metabolic, and environmental factors that are regulated by internal and external stimulators $[7,9,21,29,74,80,86,129-131]$. Due to the large diversity of BSs and complexity associated with plant growth and developmental regulation, it is likely that there will be several mechanisms regulating growth, development and responses to various stressors $[28,34,42,43,74,80,86,129,131,132]$. For a specific group of BSs such as vermicomposts and their various "teas," the scientific evidence is indicative that vermi-linked BSs enhanced plant growth and development through bio-stimulatory actions of various phytohormones present in it $[28,70,75,81,130]$. One could envisage that various groups of BSs would employ different mechanisms in accordance with their intrinsic chemistry and molecular mechanisms. 
In general, BSs promote growth, development, and resilience to abiotic stresses by exerting a bio-stimulatory effect on target plant due to phytohormones, secondary metabolites, and organic and inorganic nutrients $[28,42,66,94,95,129,131]$. Furthermore, application of BSs was reported to stimulate seed germination, seedling growth, and crop productivity by promoting primary and secondary metabolisms through the bio-stimulatory actions of signaling bioactive molecules existing in BSs [21,29,34,75]. A recent study by Briglia and coworkers [132] reported that BS application upregulated several genes involved in hormone metabolisms and biosynthesis, regulating nitrogen metabolisms and mineral transport in maize. Interestingly, researchers have reported that BSs effectively enhanced yield, nutritional and functional attributes of a wide range of fruits and vegetables $[112,133,134]$. Trichoderma-based BSs were reported to enhance biosynthesis and accumulation of phytochemicals such as ascorbic acid by regulating secondary plant metabolism, providing several health benefits to consumer [38,94,95,112]. Similarly, Carillo and co-workers [134] demonstrated that application of BSs on plum tomatoes enhanced the levels of lycopene, asparagine, and $\gamma$-aminobutyric acid by stimulating secondary metabolism and enhancing nutritional quality of fruits. Furthermore, AMF was able to modulate plant secondary metabolites' synthesis, thereby improving the health-promoting attributes of fruits and vegetables [135]. A recent study by Di Mola and co-workers [136] indicated that legumederived PHs were able to enhance antioxidant contents of green leafy vegetables, thereby improving the vital health benefits in consumer diet. Their study further revealed that PHs could further modify primary and secondary metabolism in spinach, thus contributing to various phytochemicals associated with numerous health-promoting attributes. Foliar application of SWEs (A. nodosum) was reported to increase health-promoting phenolics and flavonoids [137]. Moreover, Sani and co-workers [138] stated that both microbial and non-microbial BSs assisted in modifying primary and secondary metabolisms that led to synthesis and accumulation of antioxidants associated with health benefits. The combined application of Trichoderma + SWEs (A. nodosum) enhanced growth, nutritional quality, and mineral contents of organically grown tomatoes [138]. Similarly, a combination of Trichoderma-based BSs and bio-fortified spent mushroom substrate (SMS) improved nutritional quality of tomato through the synthesis and higher accumulation of TSS (total soluble sugars), carotenoids, polyphenols, and mineral contents [139]. Moreover, a plethora of recent research documented numerous beneficial effects of BSs on growth, physiology, yield, and quality, summarized in Table 1.

Table 1. Biostimulatory effect of biostimulants in enhancing crop physiology, productivity, and quality.

\begin{tabular}{|c|c|c|c|}
\hline BSs Applied & Crop & Effect on Crop Growth, Yield and Quality & Reference \\
\hline SWEs (Ascophyllum nodosum) & Wheat & Increased in grain yield and protein quantity & [140] \\
\hline $\begin{array}{l}\text { SWEs (E. maxima, A. nodosum, } \\
\text { Sargassum sp.) }\end{array}$ & Tomato & $\begin{array}{c}\text { Increased mineral (Fe, } \mathrm{Zn}) \text { content, enhanced } \\
\text { germination, plant height, chlorophyll content, yield } \\
\text { Expression of } 6 \text { flowering genes, increased flower bud } \\
\text { and fruits }\end{array}$ & [141-143] \\
\hline $\begin{array}{c}\text { SWEs } \\
\text { (Sargassum swartzii) }\end{array}$ & Cowpea & Increased phenolic and flavonoid content & [144] \\
\hline $\begin{array}{l}\text { SWEs (A. nodosum, } \\
\text { Laminaria ochroleuca) }\end{array}$ & Broccoli & $\begin{array}{l}\text { Increased antioxidants, flavonoids, and phenolic } \\
\text { Enhanced both glucosinolates and phenolic compounds }\end{array}$ & {$[145,146]$} \\
\hline SWEs (E. intestinelis) & Cucumber & Increased mineral (Fe, Mn, $\mathrm{Zn})$ content of fruits, yield & [147] \\
\hline SWEs (A. nodosum) & Pepper & Increased growth (height), chlorophyll content, yield & [148] \\
\hline SWEs (Ecklonia maxima) & Spinach & $\begin{array}{l}\text { Increased leaf number, chlorophyll, carotenoids, } \\
\text { proteins, phytohormones, and phenolic acid }\end{array}$ & [149] \\
\hline $\begin{array}{c}\text { SWEs } \\
\text { (commercial mixture) }\end{array}$ & Maize & $\begin{array}{l}\text { Enhanced carbohydrate, organic substance and } \\
\text { phosphorus metabolism, increased PGPR in rhizosphere }\end{array}$ & [150] \\
\hline
\end{tabular}


Table 1. Cont.

\begin{tabular}{|c|c|c|c|}
\hline BSs Applied & Crop & Effect on Crop Growth, Yield and Quality & Reference \\
\hline SWEs $(A$. nodosum $)$ & Strawberry & Increased $10 \%$ marketable yield & [151] \\
\hline SWEs (Ecklonia maxima) & Common bean & $\begin{array}{l}\text { Increased yield and anthocyanins content in the seeds } \\
\text { Increased synthesis of phenolics, flavonoid, } \\
\text { anthocyanins and antioxidant activities }\end{array}$ & {$[152,153]$} \\
\hline HSs & Maize & $\begin{array}{l}\text { Increased leaf biomass, chlorophyll and carotene content } \\
\text { Increased growth, grain yield and water use efficiency } \\
\text { Faster induction of a higher capacity to take up nitrate }\end{array}$ & {$[154,155]$} \\
\hline HSs & Onion & $\begin{array}{l}\text { Increased yield, carbohydrate, protein and mineral } \\
\text { contents in bulb }\end{array}$ & {$[156,157]$} \\
\hline HSs & Strawberry & Increased growth, nutritional and chemical composition & [158] \\
\hline HSs & Common bean & Increased seed yield and mineral content & [159] \\
\hline HSs & Thai basil & Increased leaf nitrogen content & [160] \\
\hline HSs & Arabidopsis & $\begin{array}{c}\text { Enzyme activation of the glycolytic pathway and } \\
\text { up-regulation of ribosomal protein }\end{array}$ & [161] \\
\hline PHs & Tomato & $\begin{array}{l}\text { Increased photosynthesis, antioxidant activities, total } \\
\text { soluble solids, mineral composition } \\
\text { Regulated the expression of genes involved in nitrate, } \\
\text { ammonium and amino acid transporters as well as the } \\
\text { key genes involved in N metabolism }\end{array}$ & [162] \\
\hline
\end{tabular}

Increased macro-and micro-nutrients in leaves, protein content in grain and yield

PHs Maize Increased growth and accumulation of N-compounds (proteins, chlorophylls and phenols)

Increased root growth and accumulation of $\mathrm{K}, \mathrm{Zn}, \mathrm{Cu}$, and $\mathrm{Mn}$ in roots

\begin{tabular}{|c|c|c|c|}
\hline AMF & Tomato & Increased foliar and root growth and protein content & [166] \\
\hline AMF & Maize & $\begin{array}{l}\text { Increased biomass and yield through biological } \\
\text { improvement of soil properties }\end{array}$ & [167] \\
\hline Trichoderma-based BSs & Lettuce, Rocket & Increased growth, yield and nutritional quality & {$[38,138,168]$} \\
\hline PGPR (Bacillus spp.) & Tomato & Increased growth and yield & [169] \\
\hline $\begin{array}{l}\text { PGPR (Bacillus } \\
\text { amyloliquefaciens) }\end{array}$ & Arabidopsis & Increased photosynthesis, biomass and seed yield & [170] \\
\hline PGPR (consortia) & Wheat & Increased root growth and nitrogen accumulation & [171] \\
\hline $\begin{array}{c}\text { PGPR (Cellulosimicrobium and } \\
\text { Pseudomonas) }\end{array}$ & Pepper & Increased phenolic compounds & [172] \\
\hline $\begin{array}{l}\text { PGPR (Azospirillum and } \\
\text { Agrobacterium) }\end{array}$ & Pea & $\begin{array}{l}\text { Increased nutrient uptake, vegetative growth, } \\
\text { chlorophyll content and antioxidant capacity }\end{array}$ & [173] \\
\hline
\end{tabular}

Abbreviations: AMF, Arbuscular mycorrhizal fungi; BSs, Biostimulants; HSs, Humic substances; PGPR, Plant growth-promoting rhizobacteria; PHs, Protein hydrolysates; SWEs, Seaweed extracts.

\section{Implications of Biostimulants in Alleviating Stress in Crop Plants}

Unfavorable climatic and soil conditions such as drought, salinity, and extreme temperature cause significant yield reduction in crops and are responsible for nearly $70 \%$ yield differences as determined by global climate analysis [174]. The global climate is predicted to change considerably in the next few decades and is likely to intensify adverse climatic extreme events affecting crop production and global food security $[1,4,20,21,29,32,95]$. In that context, non-microbial and microbial BSs have been widely touted as a promising technology to improve crop productivity and maintaining yield stability under adverse climatic conditions $[21,29,32,100]$. Although many BSs were able to enhance nutrient up- 
take, recent literature also reported that BSs could stimulate other rhizospheric microbes and plant-microbe beneficial associations, altering various metabolic and physiological mechanisms that allow them to ameliorate stress-induced adverse effects (Table 2). The stress adaptation strategies delivered by applications of microbial BSs included cell wall alteration and accumulation of high soluble solutes, leading to enhanced water retention, thereby improving the osmotic and ionic stress tolerance [95,98,113,129,175]. Interestingly, Rhizobium was shown to alleviate salt stress through the production and bio-stimulatory actions of high indole-3-acetic acid (IAA) and EPS concentrations [176]. These mechanisms were also reported to alleviate extreme temperature and drought stress in numerous agricultural and horticultural crops. Furthermore, inoculation of Azotobacter strains increased $\mathrm{K}+$ uptake and exclusion of $\mathrm{Na}+$, which mitigated the negative impact of salinity stress in wheat, ensuring increased biomass and grain yield [177]. For rain-fed field crops, inoculation of Pseudomonas putida resulted in significant improvement in heat tolerance of wheat by minimizing ROS generation [178]. Similarly, the cold-tolerant PGPR Pantoea dispersa was able to improve cold tolerance in wheat by enhancing nutrient solubilization and higher production of IAA [179]. Burkholderia phytofrman, another commonly used PGPR, was reported to increase ROS scavenging metabolites and stress-induced genes, thereby enhancing the chilling tolerance capacity in Vitis vinifera L. [180]. Interestingly, PGPR with ACC-deaminases were able to minimize ethylene-induced root inhibition, maintaining a higher root-to-shoot ratio and, consequently, achieving better growth under salt stress [181].

A recent study reported that non-microbial BSs such as SWEs were able to confer chilling stress tolerance in maize by enhancing the ROS responses through supplying micronutrients ( $\mathrm{Zn}, \mathrm{Mn}$, etc.) [182]. Similarly, SWE-based cytokinins were reported to enhance heat tolerance in bentgrass (Agrostis stolonifera L.) [183]. The PHs derived from alfalfa showed better salt tolerance in maize through bio-stimulatory actions of triacontanol (TRIA) and IAA, which resulted in a higher concentration of flavonoids, proline, and potassium [184]. PHs containing higher amino acids showed antioxidant and free radical scavenging properties in lettuce and improved root dry biomass and yield and higher levels of osmolytes and glucosinolates [35]. The application of HSs in common beans showed increased endogenous proline concentration and minimal membrane leakage, facilitating better salt tolerance in plants [49]. Apart from beneficial actions/effects of BSs on abiotic stress tolerance, several studies also reported the role of BSs in biotic stress tolerance, especially for microbial BSs, although protection against biotic stresses generally does not fall under the arbitrarily accepted definition of BSs [30,102,103,128]. However, their potential bio-stimulatory role in biotic stress tolerance, in addition to growth promotion, will be relevant for future development of novel BSs products. Some beneficial microbes are known to regulate induced systemic resistance (ISR) in plants by stimulating the immune system against a broad spectrum of pests and providing more rapid and intense actions against pathogens without compromising growth and yield [185]. Among the microbial BSs, PGPR Pseudomonas, Serratia, and Bacillus, and beneficial fungi Trichoderma spp. and Piriformospora indica have been well documented to induce ISR in various crops [186,187]. Trichoderma harzianum based commercial formulations (Trianum-Pfi) were reported to induce ISR and provide defense against soil pathogens [188]. Furthermore, ACC deaminaseproducing PGPR were able to protect plants against bacteria, fungi, and nematodes by hindering symptomatic development and minimizing disease severity [189]. For instance, the ACC deaminase producing Pseudomonas putida UW4 was able to provide protection against Pythium ultimum in cucumber [190]. 
Table 2. Biostimulatory effect of biostimulants in enhancing stress tolerance and crop performance.

\begin{tabular}{|c|c|c|c|c|}
\hline BSs Applied & Type of Stress & Crop & $\begin{array}{c}\text { Effect on Stress Tolerance and Crop } \\
\text { Performance }\end{array}$ & Reference \\
\hline SWEs (Euglena gracilis) & Drought/water stress & Tomato & $\begin{array}{l}\text { Increased antioxidants (carotenoids, } \\
\text { vitamins and phenolic acids) and } \\
\text { soluble carbohydrates (glucose, } \\
\text { fructose, and sucrose) in } \\
\text { fruits;Increase endogenous } \\
\text { indole-3-acetic acid (auxin), } \\
\text { trans-zeatin (cytokinin), and } \\
\text { jasmonic acid }\end{array}$ & {$[191,192]$} \\
\hline SWEs (A. nodosum) & Drought & Soybean & $\begin{array}{l}\text { Reduced Reactive Oxygen Species } \\
\text { (ROS), increased antioxidant enzymes } \\
\text { activity, stomatal conductance, higher } \\
\text { energy efficiency }\end{array}$ & [193] \\
\hline SWEs (Commercial) & Cold & Arabidopsis & $\begin{array}{l}\text { Increased superoxide dismutase } \\
\text { activity in the root and leaf tissue }\end{array}$ & [194] \\
\hline SWEs (Gracilaria dura) & Drought & Wheat & $\begin{array}{l}\text { Increased abscisic acid content and } \\
\text { expression of stress-protective genes }\end{array}$ & [195] \\
\hline SWEs (A. nodosum) & Drought & Spinach & $\begin{array}{l}\text { Increased leaf-water relations, growth } \\
\text { and yield }\end{array}$ & [196] \\
\hline SWEs (A. nodosum) & Drought & Arabidopsis & $\begin{array}{l}\text { Enhanced stomatal conductance and } \\
\text { water use efficiency; regulation of } \\
\text { stress-responsive genes }\end{array}$ & {$[197,198]$} \\
\hline SWEs (A. nodosum) & Heat & Tomato & $\begin{array}{l}\text { Gene transcription of protective heat } \\
\text { shock proteins and increased } \\
\text { flowering and fruit number }\end{array}$ & [199] \\
\hline SWEs (A. nodosum) & Drought & Broccoli & $\begin{array}{l}\text { Increased } \mathrm{N}, \mathrm{P}, \mathrm{K}, \mathrm{Mg}, \mathrm{Cu} \text { and } \\
\mathrm{Mn} \text { contents }\end{array}$ & [200] \\
\hline HSs & Drought & Potato & $\begin{array}{l}\text { Increased growth, photosynthetic } \\
\text { capacity and fresh tuber yield }\end{array}$ & [201] \\
\hline HSs & $\begin{array}{l}\text { Heavy metal stress } \\
\qquad(\mathrm{Cd})\end{array}$ & Wheat & $\begin{array}{c}\text { Increased activation of superoxide } \\
\text { dismutase (SOD), catalase (CAT) and } \\
\text { NADPH-oxidase (NOX) enzymes and } \\
\text { ascorbate, glutathione }\end{array}$ & [202] \\
\hline HSs & Salt & Strawberry & $\begin{array}{l}\text { Enhanced leaf water content, } \\
\text { membrane stability, chlorophyll } \\
\text { content and increased biomass } \\
\text { and yield }\end{array}$ & [203] \\
\hline HSs & Drought & Rapeseed & $\begin{array}{l}\text { Improved plants net photosynthesis } \\
\text { via increasing the rate of gas exchange } \\
\text { and electron transport flux }\end{array}$ & [204] \\
\hline PHs & Salt & Common bean & $\begin{array}{l}\text { Increased leaf photosynthetic } \\
\text { pigments contents, membrane } \\
\text { stability, relative water content }\end{array}$ & [205] \\
\hline PHs & Drought & Grapevine & $\begin{array}{l}\text { Reduced water loss, enhanced yield } \\
\text { and quality }\end{array}$ & [206] \\
\hline PHs (legume derived) & $\begin{array}{l}\text { Mineral nutritional } \\
\text { Stress (N) }\end{array}$ & Baby lettuce & $\begin{array}{c}\text { Increased fresh weight, antioxidant } \\
\text { capacity and total ascorbic } \\
\text { acid content }\end{array}$ & [207] \\
\hline PHs (legume derived) & $\begin{array}{l}\text { Mineral nutritional } \\
\text { Stress }(\mathrm{N})\end{array}$ & Baby rocket & $\begin{array}{l}\text { Increased lipophilic antioxidant } \\
\text { activity and total ascorbic acid content }\end{array}$ & [208] \\
\hline
\end{tabular}


Table 2. Cont.

\begin{tabular}{|c|c|c|c|c|}
\hline BSs Applied & Type of Stress & Crop & $\begin{array}{c}\text { Effect on Stress Tolerance and Crop } \\
\text { Performance }\end{array}$ & Reference \\
\hline PHs (legume derived) & $\begin{array}{l}\text { Mineral nutritional } \\
\text { Stress (N) }\end{array}$ & Baby spinach & $\begin{array}{l}\text { Increased lipophilic and hydrophilic } \\
\text { antioxidant activities, higher leaf } \\
\text { chlorophylls and lower nitrate content }\end{array}$ & [136] \\
\hline Trichoderma based BSs & $\begin{array}{l}\text { Mineral nutritional } \\
\text { stress }(\mathrm{N})\end{array}$ & Rocket & $\begin{array}{l}\text { Improved root } \mathrm{N} \text { uptake; increased } \\
\text { ascorbic acid, } \mathrm{K} \text { and } \mathrm{Ca} \text { contents }\end{array}$ & {$[38]$} \\
\hline AMF & Drought & Fenugreek & $\begin{array}{l}\text { Increased root fresh weight, fresh } \\
\text { plant weight and seed yield }\end{array}$ & [209] \\
\hline AMF & Salt & Wheat & $\begin{array}{l}\text { Increased photosynthesis and } \\
\text { stomatal conductance, lower intrinsic } \\
\text { water use efficiency and grain yield }\end{array}$ & [210] \\
\hline AMF & Salt & Sweet basil & $\begin{array}{c}\text { Increased chlorophyll content, water } \\
\text { use efficiency and yield }\end{array}$ & [211] \\
\hline AMF & Drought & Maize & $\begin{array}{c}\text { Increased photosynthesis, proline, } \\
\text { sugars and free amino acids; } \\
\text { up-regulation of the antioxidant } \\
\text { defense system }\end{array}$ & [212] \\
\hline AMF & Heavy metal stress & Soybean & $\begin{array}{l}\text { Retained heavy metals in roots and } \\
\text { reduced translocation of } \mathrm{Cu}, \mathrm{Pb} \text { and } \\
\mathrm{Zn} \text { and improved overall growth and } \\
\text { seed yield }\end{array}$ & [213] \\
\hline $\begin{array}{l}\text { PGPR (Pseudomonas } \\
\text { fluorescens and } \\
\text { Microccucuce } \\
\text { yunnanensis) }\end{array}$ & $\begin{array}{l}\text { Mineral nutritional } \\
\text { stress }(\mathrm{Fe})\end{array}$ & Quince & $\begin{array}{l}\text { Enhanced the expression of the genes } \\
\text { related to Fe homeostasis, increased } \\
\text { root, shoot biomass and } \\
\text { chlorophyll content }\end{array}$ & [214] \\
\hline $\begin{array}{c}\text { PGPR (Cupriavidus } \\
\text { necator and } \\
\text { Pseudomonas fluorescens) }\end{array}$ & Water stress & Maize & $\begin{array}{l}\text { Increased } \mathrm{N} \text { and } \mathrm{P} \text { use efficiency } \\
\text { and biomass }\end{array}$ & [215] \\
\hline $\begin{array}{l}\text { PGPR (Pseudomonas } \\
\text { aeruginosa and } \\
\text { Burkholderia gladioli) }\end{array}$ & $\begin{array}{l}\text { Heavy metal stress } \\
\text { (Cd) }\end{array}$ & Tomato & $\begin{array}{l}\text { Alleviated Cd toxicity and enhanced } \\
\text { phenolic compounds, organic acids } \\
\text { and osmoprotectants }\end{array}$ & [216] \\
\hline $\begin{array}{l}\text { PGPR (Enterobacter HS9 } \\
\text { and Bacillus G9) }\end{array}$ & Water Stress & Velvet bean & $\begin{array}{l}\text { Improved total biomass, water use } \\
\text { efficiency and carbon assimilation }\end{array}$ & [217] \\
\hline $\begin{array}{l}\text { PGPR (Alcaligenes } \\
\text { faecalis) }\end{array}$ & Salt & Wheat & $\begin{array}{l}\text { Improved ionic balance, increased } \\
\text { accumulation of osmolyte, } \\
\text { photosynthetic pigments and } \\
\text { improved photosystem II efficiency }\end{array}$ & [218] \\
\hline $\begin{array}{c}\text { PGPR (Azospirillum } \\
\text { brasiliense and } \\
\text { Azotobacter chroococcum) }\end{array}$ & Salt & Coriander & $\begin{array}{l}\text { Increased chlorophyll content, fresh } \\
\text { weight and yield }\end{array}$ & [219] \\
\hline $\begin{array}{l}\text { PGPR (Bacillus } \\
\text { licheniformis and } \\
\text { Pseudomonas } \\
\text { plecoglossicida) }\end{array}$ & Salt & Sunflower & $\begin{array}{l}\text { Increased fresh and dry biomass, } \\
\text { yield, enhanced up-regulation of } \\
\text { catalase (CAT), superoxide dismutase } \\
\text { (SOD) and guaiacol peroxidase (GPX) } \\
\text { antioxidant enzymes }\end{array}$ & [220] \\
\hline $\begin{array}{l}\text { PGPR (Streptomyces } \\
\text { spp.) }\end{array}$ & Drought & Tomato & $\begin{array}{c}\text { Increased leaf RWC, proline, MDA, } \\
\mathrm{H}_{2} \mathrm{O}_{2} \text { and total sugar content } \\
\text { and yield }\end{array}$ & [221] \\
\hline
\end{tabular}




\section{Exploiting Synergistic Biostimulatory Interactions among Biostimulants}

As discussed earlier, the pursuit of organic farming is to reduce dependence on agrochemicals, particularly inorganic fertilizers (e.g., phosphorus), by improving nutrient availability and NUE while maintaining soil health, soil quality, and productivity $[3,8,9,13,16,17,24]$. Microbial and non-microbial BSs have been widely reported to improve growth and protect plants from both biotic and abiotic stresses. When selected correctly, an application of these BSs would exert desired effect(s) on plants that are facing multiple abiotic constraints such as nutrient limitations, drought, salinity, heat, and concomitant biotic stresses simultaneously in a typical organic production system. Therefore, the purposeful combinations of microbial and non-microbial BSs represent a promising strategy that synergistically provide multiple beneficial effects to optimize growth and stress tolerance while enhancing yield and quality in these "low input" scenarios $[9,13,14,26]$. However, a combination of microbial and non-microbial BSs may result in three plausible outcomes: additive, antagonistic, and synergistic effects based on their interactive biostimulatory actions and mechanisms. Firstly, for additive effects, the combined effects exerted by BSs equaled the sum of their individual effects. Secondly, for antagonistic effects, the overall effect exerted by BSs delivered less than the additive effects. Lastly, synergistic effects could be observed when cumulative effects of BSs exceeded their additive effects; which is ultimately the preferred outcome. In recent years, many studies demonstrated that combined application of microbial and non-microbial BSs generally provided better benefits due to synergistic interactions among the BSs, resulting in enhanced growth, and stress protection [24,26,222-225]. For instance, microbial BSs Trichoderma virens (TG41) with a vegetal biopolymer-based $\mathrm{BSs}$ (VBP) enhanced $\mathrm{CO}_{2}$ assimilation in lettuce and increased mineral contents by $10 \%$ for $\mathrm{K}$ and $12 \%$ for $\mathrm{Mg}$ [226]. Their study further reported that a combined application of (TG41) + (VBP) interacted synergistically and enhanced the nutritional quality of lettuce by significantly increasing antioxidant activity, total ascorbic acid $(+61-91 \%)$, and total phenols $(+14 \%)$ while minimizing nitrate content. According to Sani and co-workers [138], a combined application of Trichoderma-based BSs and SWEs interacted synergistically and enhanced the growth, nutritional, functional quality (ascorbic acid, lycopene, minerals) of organically grown tomato. In addition, they found favorable synergistic interaction between Trichoderma and SWEs and the concomitant increase of soil fertility by fostering growth of rhizospheric fungal and bacterial populations, thereby increasing NUE, plant growth and with higher levels of antioxidants and minerals in their tomato experiments.

A recent study also demonstrated that $\mathrm{AMF}+\mathrm{SWEs}$ induced a favorable synergistic effect; higher biomass, leaf area, stomatal conductance, mineral concentration ( $\mathrm{N}$ and $\mathrm{P}$ ) were reported in date palm [227]. Apart from optimal conditions, few studies also reported the synergistic interactions providing better resilience in stress conditions. A combination of plant-derived PHs and microbial BSs interacted synergistically and delivered a marketable yield of greenhouse lettuce (Lactuca sativa L.) under alkalinity and salinity stress [26]. The combination of AMF + SWEs resulted in producing an additive effect in increasing root growth as well as protein and carbohydrate content of tomato [166]. Interestingly, their study also found a synergistic effect in accelerating flowering of tomato plants and further demonstrated that additive and synergistic effects were due to the interactions between microbial (AMF) and non-microbial (SWEs) BSs, thereby delivering better plant performance. Researchers working on acclimatizing pineapple plants in a greenhouse found that humic acid and PGPR (Burkholderia spp.) increased 50\% and $81 \%$, respectively, whereas their combined application resulted in achieving the best growth (105\%) [218]. The application of non-microbial BSs with AMF significantly increased the phenolic compounds, lipids, sugars, and proteins in leaves of Moringa oleifera, thus enhancing their functional properties [228]. A greenhouse study on wall rocket (Diplotaxis tenuifolia L.) demonstrated that combined application of PHs+ Trichoderma harzianum T22 interacted synergistically and increased lipophilic and hydrophilic antioxidant activity as well as ascorbic acid and chlorophyll content [229]. The study also found that combined application (PHs+ 
Trichoderma harzianum T22) also increased N, P, Mg, and $\mathrm{Na}$ contents compared to the standalone applications. Similarly, a combination of Trichoderma harzianum + Biopolymer-based BSs enhanced crop performance, nutritional and functional quality of greenhouse-grown tomato [134]. A greenhouse study on perennial wall rocket demonstrated that PHs and BSs (tropical plant extracts) interacted synergistically and significantly promoted ascorbic acid content over the stand-alone applications [230]. In addition, it was reported that combined application of SWEs and PGPR interactions led to a significant increase in growth and photosynthetic pigments in Amaranthus hybridus [231].

The application of combined AMF and potassium humate BSs on Russian olive (Elaeagnus angustifolia L.) exhibited synergistic interactions and enhanced the antioxidant defense system through increasing superoxide dismutase and glutathione reductase activity as well as phenolic content [232]. A single application of HSs and SWEs increased groundnut plant height by $34.5 \%$ and $17.2 \%$, respectively, whereas their combined application resulted in $65 \%$ compared to the sum of independent, stand-alone applications [225]. Alginic acid, a major component of SWEs, was able to promote hyphal growth in AMF, leading to enhanced $P$ availability and improved nutrient uptake in plants [65]. Furthermore, HSs and AMF showed significantly increased root dry weight in onions by 43.9 , and $12.1 \%$, whereas their synergistic effect exhibited $106.7 \%$ compared to a sole application under elevated $\mathrm{CO}_{2}$ [223]. Their study suggested that the synergistic bio-stimulatory interactions of HSs and AMF resulted in achieving higher NUE, thus enhancing onion plants' performance under elevated $\mathrm{CO}_{2}$. Similarly, a co-application of substrate with AMF (R. intraradices) and providing a subsequent HA spray at 30-day intervals delivered enhanced root biomass as well as greater chlorophyll biosynthesis compared to stand-alone applications in perennial ryegrass [224]. Moreover, Rouphael and co-workers demonstrated that endophytic fungal consortium and PHs improved crop productivity over a single application by increasing chlorophyll biosynthesis and maintaining the photosynthetic activity of PSII and leaf nutritional status [26]. In a field grown-tomato trial, a consortium of fungal and bacterial BSs delivered positive and synergistic effects on uptake of certain essential mineral nutrients $(\mathrm{K}, \mathrm{Na}$, and $\mathrm{Mn}$ ) from soil [233]. Based on the selection of literature provided, the synergistic properties among BSs are interesting and indicative of their complex biostimulation mechanisms in determining plant growth, performance and resilience. Thus, to develop the next generation of BSs with specific synergistic effects for enhanced crop growth, yield, quality, and resilience, we need to characterize the BSs individually and when they are used in a mixture.

\section{Ecological Considerations for Harnessing the Beneficial Functions of Biostimulants: Moving from Lab towards Successful Field Application}

Plant responses would be affected significantly by global climate change in terms of above and belowground interactions with the growing environment and diversity of organisms in terrestrial ecosystems. Therefore, applied BSs would need to be operative effectively in field conditions $[4,7,21,24,29,51,100]$. Several studies reported that efforts to use microbial BSs under field conditions have failed to improve crop performance consistently. The multiple-faceted interactions between plants and their symbiotic microbial species, ecological effects of plant-associated soil microbes and soil, and plant metabolic dynamics remain unclear $[21,29,86,100,175,234,235]$. For instance, we have little knowledge about the stand-alone microbial inoculants in soil after inoculation and how these inoculants interact with existing indigenous microbes while adapting to local abiotic conditions. Even with successful laboratory or greenhouse (pot, planting beds) trials, it is also unclear whether these introduced microbes could establish a compatible synergistic interaction with host plants, including aspects of molecular defense with the plant immune system under field conditions. Several factors can alter the success of microbial inoculation in agro-ecosystems, including plant-microbial compatibility, the degree of their competition with existing native microbial population, and timing of inoculation $[29,100,175,236]$. Throughout the whole growing period, this microbial community undergoes continuous interactions and suc- 
cession with above- and belowground components of the crops [237]. Therefore, even if beneficial microbial inoculants colonize the plants and the adjacent soils initially, their persistence and functionality over time in the rhizosphere are not guaranteed. Moreover, measuring the persistence of these microbial inoculants in soil poses major technical limitations, as the inoculants need to be identified and profiled from within a complex community. In addition, a stress episode may also induce existing (local) microbes to produce a variety of compounds that may ultimately affecting the entire microbial community stability. For instance, it was reported that drought-treated soils contained more antibiotics, which were produced by drought-tolerant bacteria as a physiological response to outcompete other bacteria for limited resources or possibly acting as signals to induce drought-response pathways such as biofilm formation [238]. Therefore, the uncertainly posed by complex microbial and plant interactions on soil-microbiome functionality remained a challenge to the wider usage of BSs, especially under field conditions. Interestingly, attempts have been made along these similar lines in restoration ecology where researchers used various combination of BSs and an N-fixing legume (pigeon pea) to restore highly degraded mine site soils for the purpose of re-introducing native vegetation post-mining [239].

In this context, microbial and non-microbial BSs' combined application may offer plants with better combinatorial effects through synergistic interactions favoring beneficial physiological functions to plants. For example, HSs were effective in enhancing germ tube elongation and hyphal branching of AMF, thus assisting the symbiotic expansion of AMF in onions and thereby boosting root and shoot biomass production [223]. Several studies demonstrated that combined application of AMF, Trichoderma, or PHs stimulated the uptake of bivalent cations, principally $\mathrm{Mg}^{2+}$ and $\mathrm{Fe}^{2+}$ that were required for chlorophyll biosynthesis and restoring foliar chlorophyll content to acceptable levels under adverse saline and alkaline field conditions [113,154]. Furthermore, Rouphael and co-workers [26] reported that a combined application of microbial-based BSs and PHs interacted synergistically to activate both proline and antioxidant enzymes as a strategy against oxidative damage under stress conditions and was proven more effective than a single microbial BS application. Several researchers [54,238] reported that PHs could possibly stimulate plant-associated microbiome; thus, these amino acids were serving as suitable substrates for plant-associated microbes in rhizosphere. Therefore, the determinants of plant productivity and stress responses under field conditions are dependent in part on diverse microbial communities in rhizosphere. Their underlying interactions with plants and understanding the combinatorial effects of BSs on soil microbiome function would pave the way to improve our understanding of the soil-microbe-plant continuum. With more targeted research in BS characterization and metabolism dynamics along the soil-microbe-plant continuum (e.g., BSs involved in root to shoot signaling after inoculation), we will better understand the communication dynamics of plants and microbes in rhizosphere $[21,29,235,240]$. With greater mechanistic clarity, we may be able to access the beneficial potential of these plant-microbe interactions through strategic BS usage.

\section{Concluding Remarks and Future Challenges}

Microbial and non-microbial BSs offer a promising innovative and sustainable strategy to supplement and replace agrochemicals in the near future. With greater mechanistic clarity, the judicious use of BSs should improve plant growth and resilience to biotic and abiotic stresses and deliver acceptable yield and good quality organically cultivated products. The first step is to understand and characterize the diversity of BSs using advanced analytical approaches with concomitant validation of plant performance over a wide range of conditions. The research community, growers and industrial companies are interested in identifying the bioactive elements of BSs and elucidating underlying biochemical, physiological, and molecular pathways of biostimulation. If the characterization of targeted BSs is successful, we will be able to formulate more specific BSs to meet specific species requirements and address the multitude of cultivation challenges. Nevertheless, further advanced research is needed to address several uncertainties, such as: (i) How effectively can BSs modulate the 
rhizospheric microbial population quantitatively and qualitatively in rhizosphere? (ii) How long can microbial BSs persist under field condition subsequent to their application and their underlying interactions with existing microbes? (iii) How do BSs modulate hormonal signaling under both normal and stress conditions within a plant? (iv) How and to what extent BSs stimulate microbe-derived hormones in root microbiome assembly, rhizosphere, entry to plant vascular system, and root-shoot signaling? The recent advancements in omics-based and other technologies, such as meta-transcriptomics, meta-proteomics or metabolomics, amplicon sequencing and phenotyping, will contribute to profiling of trace metabolites facilitating the soil-microbe-root-shoot processes, and consequently help assess plant performance and yield. Understanding these mechanisms will lead to the development of novel and well characterized BSs, combining microbial and non-microbial BSs strategically with specific desired synergistic bio-stimulatory action, to deliver enhanced plant growth, yield, quality, and resilience consistently in organic agriculture.

Author Contributions: M.N.H.S., managed the literature searches and wrote the first draft of the manuscript. J.W.H.Y., critically reviewed drafts, and provided additional salient literature and scientific inputs. All authors have read and agreed to the published version of the manuscript.

Funding: This research was funded by two Sveriges lantbruksuniversitet (SLU, Swedish University of Agricultural Sciences) Alnarp special scholarships (Martha och Dagny Larssons fond, 2019; Gosta och Anna-Birgit Henrikssons fond, 2020).

Institutional Review Board Statement: Not applicable.

Informed Consent Statement: Not applicable.

Data Availability Statement: Not applicable.

Conflicts of Interest: The authors declare no conflict of interest.

\section{References}

1. Ehrlich, P.R.; Harte, J. Opinion: To feed the world in 2050 will require a global revolution. Proc. Natl. Acad. Sci. USA 2015, 112, 14743-14744. [CrossRef]

2. Shiferaw, B.; Prasanna, B.M.; Hellin, J.; Bänziger, M. Crops that feed the world 6. Past successes and future challenges to the role played by maize in global food security. Food Security 2011, 3, 307-327. [CrossRef]

3. Bünemann, E.K.; Bongiorno, G.; Bai, Z.; Creamer, R.E.; De Deyn, G.; de Goede, R.; Fleskens, L.; Geissen, V.; Kuyper, T.W.; Mäder, P.; et al. Soil quality-A critical review. Soil Biol. Biochem. 2018, 120, 105-125. [CrossRef]

4. Del Buono, D. Can biostimulants be used to mitigate the effect of anthropogenic climate change on agriculture? It is time to respond. Sci. Total Environ. 2020, 751, 141763. [CrossRef] [PubMed]

5. Seiber, J.N.; Coats, J.; Duke, S.O.; Gross, A.D. Biopesticides: State of the art and future opportunities. J. Agric. Food Chem. 2014, 62, 11613-11619. [CrossRef] [PubMed]

6. Pimentel, D. Amounts of pesticides reaching target pests: Environmental impacts and ethics. J. Agric. Environ. Ethics 1995, 8 , 17-29. [CrossRef]

7. Seneviratne, G.; Kulasooriya, S.A. Reinstating soil microbial diversity in agroecosystems: The need of the hour for sustainability and health. Agric. Ecosyst. Environ. 2013, 164, 181-182. [CrossRef]

8. Huang, R.; McGrath, S.P.; Hirsch, P.R.; Clark, I.M.; Storkey, J.; Wu, L.; Zhou, J.; Liang, Y. Plant-microbe networks in soil are weakened by century-long use of inorganic fertilizers. Microb. Biotechnol. 2019, 12, 1464-1475. [CrossRef]

9. Reganold, J.P.; Wachter, J.M. Organic agriculture in the twenty-first century. Nat. Plants 2016, 2, 15221. [CrossRef] [PubMed]

10. Dorais, M.; Alsanius, B.W. Recent advances in organic horticulture technology and management. Sci. Hortic. 2016, 208, 1-2. [CrossRef]

11. Parvin, S.; Sani, M.N.H.; Modak, S.; Shahriar, S.A.; Uddain, J. Efficacy of different organic manures on growth and yield performance of organically grown tomato. Asian J. Adv. Agric. Res. 2019, 8, 1-10. [CrossRef]

12. Dorais, M. Organic production of vegetables: State of the art and challenges. Can. J. Plant Sci. 2007, 87, 1055-1066. [CrossRef]

13. Seufert, V.; Ramankutty, N.; Foley, J.A. Comparing the yields of organic and conventional agriculture. Nature 2012, 485, 229-232. [CrossRef] [PubMed]

14. De Ponti, T.; Rijk, B.; Van Ittersum, M.K. The crop yield gap between organic and conventional agriculture. Agric. Syst. 2012, 108, 1-9. [CrossRef]

15. Ponisio, L.C.; M’Gonigle, L.K.; Mace, K.C.; Palomino, J.; de Valpine, P.; Kremen, C. Diversification practices reduce organic to conventional yield gap. Proc. R. Soc. B 2015, 282, 20141396. [CrossRef]

16. Trewavas, A. Urban myths of organic farming. Nature 2001, 410, 409-410. [CrossRef] [PubMed] 
17. Berry, P.M.; Sylvester-Bradley, R.; Philipps, L.; Hatch, D.J.; Cuttle, S.P.; Rayns, F.W.; Gosling, P. Is the productivity of organic farms restricted by the supply of available nitrogen? Soil Use Manag. 2006, 18, 248-255. [CrossRef]

18. Van Bueren, E.L.; Jones, S.S.; Tamm, L.; Murphy, K.M.; Myers, J.R.; Leifert, C.; Messmer, M.M. The need to breed crop varieties suitable for organic farming, using wheat, tomato and broccoli as examples: A review. NJAS-Wagening. J. Life Sci. 2011, 58, 193-205. [CrossRef]

19. Orsini, F.; Maggio, A.; Rouphael, Y.; De Pascale, S. "Physiological quality" of organically grown vegetables. Sci. Hortic. 2016, 208, 131-139. [CrossRef]

20. Pereira, A. Plant abiotic stress challenges from the changing environment. Front. Plant Sci. 2016, 7, 1123. [CrossRef]

21. Gupta, A.; Rico-Medina, A.; Caño-Delgado, A.I. The physiology of plant responses to drought. Science 2020, 368, 266-269. [CrossRef]

22. Zetterberg, C.; Björnberg, K.E. Time for a new EU regulatory framework for GM crops? J. Agric Env. Ethics 2017, 30, 325-347. [CrossRef]

23. Barbieri, G.; Colonna, E.; Rouphael, Y.; De Pascale, S. Effect of the farming system and postharvest frozen storage on quality attributes of two strawberry cultivars. Fruits 2015, 70, 351-360. [CrossRef]

24. De Pascale, S.; Rouphael, Y.; Colla, G. Plant biostimulants: Innovative tool for enhancing plant nutrition in organic farming. Eur. J. Hortic. Sci. 2017, 82, 277-285. [CrossRef]

25. Colla, G.; Rouphael, Y. Biostimulants in horticulture. Sci. Hortic. 2015, 196, 1-134. [CrossRef]

26. Rouphael, Y.; Cardarelli, M.; Bonini, P.; Colla, G. Synergistic action of a microbial-based biostimulant and a plant derived-protein hydrolysate enhances lettuce tolerance to alkalinity and salinity. Front. Plant Sci. 2017, 8, 131. [CrossRef]

27. Abbott, L.K.; Macdonald, L.M.; Wong, M.T.F.; Webb, M.J.; Jenkins, S.N.; Farrell, M. Potential roles of biological amendments for profitable grain production-a review. Agric. Ecosyst. Environ. 2018, 256, 34-50. [CrossRef]

28. Wong, W.S.; Zhong, H.T.; Cross, A.T.; Yong, J.W.H. Plant biostimulants in vermicomposts: Characteristics and plausible mechanisms. In The Chemical Biology of Plant Biostimulants; Geelen, D., Xu, L., Eds.; Wiley: Hoboken, NJ, USA, 2020; pp. 155-180.

29. de Vries, F.T.; Griffiths, R.I.; Knight, G.; Nicolitch, O.; Williams, A. Harnessing rhizosphere microbiomes for drought-resilient crop production. Science 2020, 39, 1620-1630. [CrossRef]

30. du Jardin, P. Plant biostimulants: Definition, concept, main categories and regulation. Sci. Hortic. 2015, 196, 3-14. [CrossRef]

31. Caradonia, F.; Battaglia, V.; Righi, L.; Pascali, G.; La Torre, A. Plant biostimulant regulatory framework: Prospects in Europe and current situation at international level. J. Plant Growth Regul. 2019, 38, 438-448. [CrossRef]

32. Rouphael, Y.; Spíchal, L.; Panzarová, K.; Casa, R.; Colla, G. High-throughput plant phenotyping for developing novel biostimulants: From lab to field or from field to lab? Front. Plant Sci. 2018, 9, 1197. [CrossRef] [PubMed]

33. Critchley, A.T.; Critchley, J.S.; Norrie, J.; Gupta, S.; Van Staden, J. Perspectives on the global biostimulant market: Applications, volumes, and values, 2016 data and projections to 2022. In Biostimulants for Crops from Seed Germination to Plant Development; Gupta, S., van Staden, J., Eds.; Academic Press: Cambridge, MA, USA, 2021; pp. 289-296.

34. Calvo, P.; Nelson, L.; Kloepper, J.W. Agricultural uses of plant biostimulants. Plant Soil 2014, 383, 3-41. [CrossRef]

35. Lucini, L.; Rouphael, Y.; Cardarelli, M.; Canaguier, R.; Kumar, P.; Colla, G. The effect of a plant-derived biostimulant on metabolic profiling and crop performance of lettuce grown under saline conditions. Sci. Hortic. 2015, 182, 124-133. [CrossRef]

36. Povero, G.; Mejia, J.F.; Di Tommaso, D.; Piaggesi, A.; Warrior, P. A systematic approach to discover and characterize natural plant biostimulants. Front. Plant Sci. 2016, 7, 435. [CrossRef]

37. Bulgari, R.; Morgutti, S.; Cocetta, G.; Negrini, N.; Farris, S.; Calcante, A.; Spinardi, A.; Ferrari, E.; Mignani, I.; Oberti, R.; et al Evaluation of borage extracts as potential biostimulant using a phenomic, agronomic, physiological, and biochemical approach. Front. Plant Sci. 2017, 8, 935. [CrossRef] [PubMed]

38. Fiorentino, N.; Ventorino, V.; Woo, S.L.; Pepe, O.; De Rosa, A.; Gioia, L.; Romano, I.; Lombardi, N.; Napolitano, M.; Colla, G.; et al. Trichoderma-based biostimulants modulate rhizosphere microbial populations and improve $\mathrm{N}$ uptake efficiency, yield, and nutritional quality of leafy vegetables. Front. Plant Sci. 2018, 9, 743. [CrossRef]

39. Ruzzi, M.; Aroca, R. Plant growth-promoting rhizobacteria act as biostimulants in horticulture. Sci. Hortic. 2015, 196, 124-134. [CrossRef]

40. Rajput, R.S.; Ram, R.M.; Vaishnav, A.; Singh, H.B. Microbe-based novel biostimulants for sustainable crop production. In Microbial Diversity in Ecosystem Sustainability and Biotechnological Applications; Satyanarayana, T., Johri, B.N., Das, S.K., Eds.; Springer: Singapore, 2019; pp. 109-144.

41. Jindo, K.; Martim, S.A.; Navarro, E.C.; Pérez-Alfocea, F.; Hernandez, T.; Garcia, C.; Aguiar, N.O.; Canellas, L.P. Root growth promotion by humic acids from composted and non-composted urban organic wastes. Plant Soil 2012, 353, 209-220. [CrossRef]

42. Olaetxea, M.; De Hita, D.; Garcia, C.A.; Fuentes, M.; Baigorri, R.; Mora, V.; Garcia-Mina, J.M. Hypothetical framework integrating the main mechanisms involved in the promoting action of rhizospheric humic substances on plant root-and shoot-growth. Appl. Soil Ecol. 2018, 123, 521-537. [CrossRef]

43. Rouphael, Y.; Colla, G. Synergistic biostimulatory action: Designing the next generation of plant biostimulants for sustainable agriculture. Front. Plant Sci. 2018, 9, 1655. [CrossRef]

44. García, A.C.; Santos, L.A.; de Souza, L.G.A.; Tavares, O.C.H.; Zonta, E.; Gomes, E.T.M.; Berbara, R.L.L. Vermicompost humic acids modulate the accumulation and metabolism of ROS in rice plants. J. Plant Physiol. 2016, 192, 56-63. [CrossRef] [PubMed] 
45. Jannin, L.; Arkoun, M.; Ourry, A.; Laîné, P.; Goux, D.; Garnica, M.; Fuentes, M.; Francisco, S.S.; Baigorri, R.; Cruz, F.; et al. Microarray analysis of humic acid effects on Brassica napus growth: Involvement of N, C and S metabolisms. Plant Soil 2012, 359, 297-319. [CrossRef]

46. Trevisan, S.; Botton, A.; Vaccaro, S.; Vezzaro, A.; Quaggiotti, S.; Nardi, S. Humic substances affect Arabidopsis physiology by altering the expression of genes involved in primary metabolism, growth and development. Environ. Exp. Bot. 2011, 74, 45-55. [CrossRef]

47. Olivares, F.L.; Aguiar, N.O.; Rosa, R.C.C.; Canellas, L.P. Substrate biofortification in combination with foliar sprays of plant growth promoting bacteria and humic substances boosts production of organic tomatoes. Sci. Hortic. 2015, 183, 100-108. [CrossRef]

48. Schiavon, M.; Pizzeghello, D.; Muscolo, A.; Vaccaro, S.; Francioso, O.; Nardi, S. High molecular size humic substances enhance phenylpropanoid metabolism in maize (Zea mays L.). J. Chem. Ecol. 2010, 36, 662-669. [CrossRef] [PubMed]

49. Aydin, A.; Kant, C.; Turan, M. Humic acid application alleviates salinity stress of bean (Phaseolus vulgaris L.) plants decreasing membrane leakage. Afr. J. Agric. Res. 2012, 7, 1073-1086. [CrossRef]

50. Petrozza, A.; Santaniello, A.; Summerer, S.; Di Tommaso, G.; Di Tommaso, D.; Paparelli, E.; Piaggesi, A.; Perata, P.; Cellini, F. Physiological responses to Megafol ${ }^{\circledR}$ treatments in tomato plants under drought stress: A phenomic and molecular approach. Sci. Hortic. 2014, 174, 185-192. [CrossRef]

51. Halpern, M.; Bar-Tal, A.; Ofek, M.; Minz, D.; Muller, T.; Yermiyahu, U. The use of biostimulants for enhancing nutrient uptake. Adv. Agron. 2015, 130, 141-174.

52. Colla, G.; Rouphael, Y.; Canaguier, R.; Svecova, E.; Cardarelli, M. Biostimulant action of a plant-derived protein hydrolysate produced through enzymatic hydrolysis. Front. Plant Sci. 2014, 5, 448. [CrossRef]

53. Madende, M.; Hayes, M. Fish by-product use as biostimulants: An overview of the current state of the art, including relevant legislation and regulations within the EU and USA. Molecules 2020, 25, 1122. [CrossRef]

54. Colla, G.; Hoagland, L.; Ruzzi, M.; Cardarelli, M.; Bonini, P.; Canaguier, R.; Rouphael, Y. Biostimulant action of protein hydrolysates: Unraveling their effects on plant physiology and microbiome. Front. Plant Sci. 2017, 8, 2202. [CrossRef]

55. Nardi, S.; Pizzeghello, D.; Schiavon, M.; Ertani, A. Plant biostimulants: Physiological responses induced by protein hydrolyzedbased products and humic substances in plant metabolism. Scientia. Agric. 2016, 73, 18-23. [CrossRef]

56. Colla, G.; Rouphael, Y.; Di Mattia, E.; El-Nakhel, C.; Cardarelli, M. Co-inoculation of Glomus intraradices and Trichoderma atroviride acts as a biostimulant to promote growth, yield and nutrient uptake of vegetable crops. J. Sci. Food Agric. 2015, 95, 1706-1715. [CrossRef] [PubMed]

57. Stirk, W.A.; Tarkowská, D.; Turečová, V.; Strnad, M.; van Staden, J. Abscisic acid, gibberellins and brassinosteroids in Kelpak ${ }^{\circledR}$, a commercial seaweed extract made from Ecklonia maxima. J. Appl. Phycol. 2014, 26, 561-567. [CrossRef]

58. Goñi, O.; Quille, P.; O'Connell, S. Seaweed carbohydrates. In The Chemical Biology of Plant Biostimulants; Geelen, D., Xu, L., Eds.; Wiley: Hoboken, NJ, USA, 2020; pp. 57-96.

59. Stirk, W.A.; Rengasamy, K.R.R.; Kulkarni, M.G.; van Staden, J. Plant biostimulants from seaweeds. In The Chemical Biology of Plant Biostimulants; Geelen, D., Xu, L., Eds.; Wiley: Hoboken, NJ, USA, 2020; pp. 33-56.

60. MacKinnon, S.L.; Hiltz, D.; Ugarte, R.; Craft, C.A. Improved methods of analysis for betaines in Ascophyllum nodosum and its commercial seaweed extracts. J. Appl. Phycol. 2010, 22, 489-494. [CrossRef]

61. El Boukhari, M.E.M.; Barakate, M.; Bouhia, Y.; Lyamlouli, K. Trends in seaweed extract based biostimulants: Manufacturing process and beneficial effect on soil-plant systems. Plants 2020, 9, 359. [CrossRef]

62. Castaings, L.; Marchive, C.; Meyer, C.; Krapp, A. Nitrogen signalling in Arabidopsis: How to obtain insights into a complex signalling network. J. Exp. Bot. 2011, 62, 1391-1397. [CrossRef]

63. Khan, W.; Rayirath, U.P.; Subramanian, S.; Jithesh, M.N.; Rayorath, P.; Hodges, D.M.; Critchley, A.T.; Craigie, J.S.; Norrie, J.; Prithiviraj, B. Seaweed extracts as biostimulants of plant growth and development. J. Plant. Growth Regul. 2009, 28, 386-399. [CrossRef]

64. Battacharyya, D.; Babgohari, M.Z.; Rathor, P.; Prithiviraj, B. Seaweed extracts as biostimulants in horticulture. Sci. Hortic. 2015, 196, 39-48. [CrossRef]

65. Kuwada, K.; Wamocho, L.S.; Utamura, M.; Matsushita, I.; Ishii, T. Effect of red and green algal extracts on hyphal growth of arbuscular mycorrhizal fungi, and on mycorrhizal development and growth of papaya and passion fruit. Agron. J. 2006, 98, 1340-1344. [CrossRef]

66. De Saeger, J.; Van Praet, S.; Vereecke, D.; Park, J.; Jacques, S.; Han, T.; Depuydt, S. Toward the molecular understanding of the action mechanism of Ascophyllum nodosum extracts on plants. J. Appl. Phycol. 2020, 32, 573-597. [CrossRef]

67. Xu, L.; Geelen, D. Developing biostimulants from agro-food and industrial by-products. Front. Plant Sci. 2018, 9, 1567. [CrossRef]

68. Poveda, J. Insect frass in the development of sustainable agriculture. A review. Agron. Sustain. Dev. 2021, 41, 1-10. [CrossRef]

69. Wang, Q.; Ren, X.; Sun, Y.; Zhao, J.; Awasthi, M.K.; Liu, T.; Zhang, Z. Improvement of the composition and humification of different animal manures by black soldier fly bioconversion. J. Clean. Prod. 2021, 278, 123397. [CrossRef]

70. Arancon, N.Q.; Solarte, Z. Vermiculture in greenhouse plants, field crop production, and hydroponics. In The Oxford Encyclopaedia of Agriculture and the Environment; Hazlet, R.W., Ed.; Oxford University Press: Oxford, UK, 2020. [CrossRef]

71. Benazzouk, S.; Dobrev, P.I.; Djazouli, Z.E.; Motyka, V.; Lutts, S. Positive impact of vermicompost leachate on salt stress resistance in tomato (Solanum lycopersicum L.) at the seedling stage: A phytohormonal approach. Plant Soil 2020, 446, 145-162. [CrossRef] 
72. Zhang, H.; Tan, S.N.; Teo, C.H.; Yew, Y.R.; Ge, L.; Chen, X.; Yong, J.W.H. Analysis of phytohormones in vermicompost using a novel combinative sample preparation strategy of ultrasound-assisted extraction and solid-phase extraction coupled with liquid chromatography-tandem mass spectrometry. Talanta 2015, 139, 189-197. [CrossRef]

73. Zhang, K.; Letham, D.S.; John, P.C.L. Cytokinin controls the cell cycle at mitosis by stimulating the tyrosine dephosphorylation and activation of $\mathrm{p}^{34 \mathrm{cdc} 2}$-like H1 histone kinase. Planta 1996, 200, 2-12. [CrossRef] [PubMed]

74. D'Agostino, I.B.; Kieber, J.J. Molecular mechanisms of cytokinin action. Curr. Opin. Plant Biol. 1999, 2, 359-364. [CrossRef]

75. Wong, W.S.; Tan, S.N.; Ge, L.; Chen, X.; Yong, J.W.H. The importance of phytohormones and microbes in biofertilizers: A critical review. In Bacterial Metabolites in Sustainable Agroecosystem; Maheshwari, D.K., Ed.; Springer: Berlin/Heidelberg, Germany, 2015; pp. 105-158.

76. Zhang, H.; Tan, S.N.; Wong, W.S.; Ng, C.Y.L.; Teo, C.H.; Ge, L.; Yong, J.W.H. Mass spectrometric evidence for the occurrence of plant growth promoting cytokinins in vermicompost tea. Biol. Fertil. Soils 2014, 50, 401-403. [CrossRef]

77. Ge, L.; Yong, J.W.H.; Tan, S.N.; Yang, X.H.; Ong, E.S. Analysis of positional isomers of hydroxylated aromatic cytokinins by micellar electrokinetic chromatography. Electrophoresis 2005, 26, 1768-1777. [CrossRef] [PubMed]

78. Ge, L.; Yong, J.W.H.; Tan, S.N.; Hua, L.; Ong, E.S. Analyses of gibberellins in coconut water by partial filling-micellar electrokinetic chromatography-mass spectrometry with reversal of electroosmotic flow. Electrophoresis 2008, 29, 2126-2134. [CrossRef] [PubMed]

79. Darmawan, R.; Dewi, V.G.P.; Rizaldi, M.A.; Juliastuti, S.R.; Gunawan, S.; Aparamarta, H.W.; Wiguno, A. Production of liquid bio-fertilizer from old coconut water and molasses using consortium microbes. IOP Conf. Ser. Mater. Sci. Eng. 2020, 845, 012007. [CrossRef]

80. Kieber, J.J.; Schaller, G.E. Cytokinin signaling in plant development. Development 2018, 145, dev149344. [CrossRef] [PubMed]

81. Aremu, A.O.; Stirk, W.A.; Kulkarni, M.G.; Tarkowská, D.; Turečková, V.; Gruz, J.; Van Staden, J. Evidence of phytohormones and phenolic acids variability in garden-waste-derived vermicompost leachate, a well-known plant growth stimulant. Plant Growth Regul. 2015, 75, 483-492. [CrossRef]

82. Canellas, L.P.; Olivares, F.L.; Aguiar, N.O.; Jones, D.L.; Nebbioso, A.; Mazzei, P.; Piccolo, A. Humic and fulvic acids as biostimulants in horticulture. Sci. Hortic. 2015, 196, 15-27. [CrossRef]

83. Huang, S.; Zheng, X.; Luo, L.; Ni, Y.; Yao, L.; Ni, W. Biostimulants in bioconversion compost of organic waste: A novel booster in sustainable agriculture. J. Clean. Prod. 2021, 319, 128704. [CrossRef]

84. Annunziata, M.G.; Ciarmiello, L.F.; Woodrow, P.; Dell'Aversana, E.; Carillo, P. Spatial and temporal profile of glycine betaine accumulation in plants under abiotic stresses. Front. Plant Sci. 2019, 10, 230. [CrossRef] [PubMed]

85. Tisarum, R.; Theerawitaya, C.; Samphumphung, T.; Takabe, T.; Cha-um, S. Exogenous foliar application of glycine betaine to alleviate water deficit tolerance in two Indica rice genotypes under greenhouse conditions. Agronomy 2019, 9, 138. [CrossRef]

86. Pozo, M.J.; López-Ráez, J.A.; Azcón-Aguilar, C.; García-Garrido, J.M. Phytohormones as integrators of environmental signals in the regulation of mycorrhizal symbioses. New Phytol. 2015, 205, 1431-1436. [CrossRef] [PubMed]

87. Dubey, A.; Kumar, A.; Khan, M.L. Role of biostimulants for enhancing abiotic stress tolerance in Fabaceae plants. In The Plant Family Fabaceae; Springer: Singapore, 2020; pp. 223-236.

88. Behie, S.W.; Bidochka, M.J. Nutrient transfer in plant-fungal symbioses. Trends Plant Sci. 2014, 19, 734-740. [CrossRef]

89. Jiang, F.; Zhang, L.; Zhou, J.; George, T.S.; Feng, G. Arbuscular mycorrhizal fungi enhance mineralisation of organic phosphorus by carrying bacteria along their extraradical hyphae. New Phytol. 2021, 230, 304-315. [CrossRef] [PubMed]

90. Johnson, N.C.; Graham, J.H. The continuum concept remains a useful framework for studying mycorrhizal functioning. Plant Soil 2013, 363, 411-419. [CrossRef]

91. Bahram, M.; Hildebrand, F.; Forslund, S.K.; Anderson, J.L.; Soudzilovskaia, N.A.; Bodegom, P.M. Structure and function of the global topsoil microbiome. Nature 2018, 560, 233-237. [CrossRef] [PubMed]

92. Johnson, D.; Gilbert, L. Interplant signalling through hyphal networks. New Phytol. 2015, 205, 1448-1453. [CrossRef]

93. Simard, S.W.; Beiler, K.J.; Bingham, M.A.; Deslippe, J.R.; Philip, L.J.; Teste, F.P. Mycorrhizal networks: Mechanisms, ecology and modelling. Fungal Biol. Rev. 2012, 26, 39-60. [CrossRef]

94. López-Bucio, J.; Pelagio-Flores, R.; Herrera-Estrella, A. Trichoderma as biostimulant: Exploiting the multilevel properties of a plant beneficial fungus. Sci. Hortic. 2015, 196, 109-123. [CrossRef]

95. Begum, N.; Qin, C.; Ahanger, M.A.; Raza, S.; Khan, M.I.; Ashraf, M.; Ahmed, N.; Zhang, L. Role of arbuscular mycorrhizal fungi in plant growth regulation: Implications in abiotic stress tolerance. Front. Plant Sci. 2019, 10, 1068. [CrossRef]

96. Bitterlich, M.; Rouphael, Y.; Graefe, J.; Franken, P. Arbuscular mycorrhizas: A promising component of plant production systems provided favorable conditions for their growth. Front. Plant Sci. 2018, 9, 1329. [CrossRef]

97. Candido, V.; Campanelli, G.; D’Addabbo, T.; Castronuovo, D.; Perniola, M.; Camele, I. Growth and yield promoting effect of artificial mycorrhization on field tomato at different irrigation regimes. Sci. Hortic. 2015, 187, 35-43. [CrossRef]

98. Lugtenberg, B.; Kamilova, F. Plant growth promoting rhizobacteria. Annu. Rev. Microbiol. 2009, 63, 541-556. [CrossRef]

99. Saharan, B.S.; Nehra, V. Plant growth promoting rhizobacteria: A critical review. Life Sci. Med. Res. 2011, 21, 1-30.

100. Pérez-Montaño, F.; Alías-Villegas, C.; Bellogín, R.A.; del Cerro, P.; Espuny, M.R.; Jiménez-Guerrero, I.; López-Baena, F.J.; Ollero, F.J.; Cubo, T. Plant growth promotion in cereal and leguminous agricultural important plants: From microorganism capacities to crop production. Microbiol. Res. 2014, 169, 325-336. [CrossRef] 
101. Jog, R.; Nareshkumar, G.; Rajkumar, S. Enhancing soil health and plant growth promotion by actinomycetes. In Plant Growth Promoting Actinobacteria; Subramaniam, G., Arumugam, S., Rajendran, V., Eds.; Springer Nature: Berlin/Heidelberg, Germany, 2016; pp. 33-45.

102. Swarnalakshmi, K.; Senthilkumar, M.; Ramakrishnan, B. Endophytic actinobacteria: Nitrogen fixation, phytohormone production, and antibiosis. In Plant Growth Promoting Actinobacteria; Subramaniam, G., Arumugam, S., Rajendran, V., Eds.; Springer Nature: Berlin/Heidelberg, Germany, 2016; pp. 123-145.

103. Olanrewaju, O.S.; Babalola, O.O. Streptomyces: Implications and interactions in plant growth promotion. Appl. Microbiol. Biotechnol. 2019, 103, 1179-1188. [CrossRef]

104. Das, P.; Singh, S.K.; Singh, P.; Zeyad, M.T.; Aamir, M.; Upadhyay, R.S. Actinomycetes as biostimulants and their application in agricultural practices. In Microbiome Stimulants for Crops; White, J., Kumar, A., Droby, S., Eds.; Woodhead Publishing: Duxford/Kidlington, UK, 2021; pp. 267-282. [CrossRef]

105. Saia, S.; Rappa, V.; Ruisi, P.; Abenavoli, M.R.; Sunseri, F.; Giambalvo, D.; Frenda, A.S.; Martinelli, F. Soil inoculation with symbiotic microorganisms promotes plant growth and nutrient transporter genes expression in durum wheat. Front. Plant Sci. 2015, 6, 815 [CrossRef]

106. Chen, Y.; Nobili, M.D.; Aviad, T. Stimulatory effects of humic substances on plant growth. Soil organic matter in sustainable agriculture. In Soil Organic Matter in Sustainable Agriculture; Magdoff, F., Weil, R.R., Eds.; CRC Press: New York, NY, USA, 2004; pp. 103-129.

107. García-Mina, J.M.; Antolín, M.C.; Sanchez-Diaz, M. Metal-humic complexes and plant micronutrient uptake: A study based on different plant species cultivated in diverse soil types. Plant Soil 2004, 258, 57-68. [CrossRef]

108. Farrell, M.; Prendergast-Miller, M.; Jones, D.L.; Hill, P.W.; Condron, L.M. Soil microbial organic nitrogen uptake is regulated by carbon availability. Soil Biol. Biochem. 2014, 77, 261-267. [CrossRef]

109. Arioli, T.; Mattner, S.W.; Hepworth, G.; McClintock, D.; McClintock, R. Effect of seaweed extract application on wine grape yield in Australia. J. Appl. Phycol. 2021, 33, 1883-1891. [CrossRef]

110. Hegazy, E.A.; Abdel-Rehim, H.; Diaa, D.A.; El-Barbary, A. Controlling of degradation effects in radiation processing of polymers In Controlling of Degradation Effects in Radiation Processing of Polymers; International Atomic Energy Agency: Vienna, Austria, 2009; p. 67.

111. Rodríguez, H.; Fraga, R.; Gonzalez, T.; Bashan, Y. Genetics of phosphate solubilization and its potential applications for improving plant growth-promoting bacteria. Plant Soil 2006, 287, 15-21. [CrossRef]

112. Sani, M.N.H.; Hasan, M.; Uddain, J.; Subramaniam, S. Impact of application of Trichoderma and biochar on growth, productivity, and nutritional quality of tomato under reduced NPK fertilization. Ann. Agric. Sci. 2020, 65, 107-115. [CrossRef]

113. Rouphael, Y.; Cardarelli, M.; Colla, G. Role of arbuscular mycorrhizal fungi in alleviating the adverse effects of acidity and aluminium toxicity in zucchini squash. Sci. Hortic. 2015, 188, 97-105. [CrossRef]

114. Rouphael, Y.; Cardarelli, M.; Di Mattia, E.; Tullio, M.; Rea, E.; Colla, G. Enhancement of alkalinity tolerance in two cucumber genotypes inoculated with an arbuscular mycorrhizal biofertilizer containing Glomus intraradices. Biol. Fertil. Soils 2010, 46, 499-509. [CrossRef]

115. Morrison, E.; Lagos, L.; Al-Agely, A.; Glaab, H.; Johnson, W.; Jorquera, M.A.; Ogram, A. Mycorrhizal inoculation increases genes associated with nitrification and improved nutrient retention in soil. Biol. Fertil. Soils 2017, 53, 275-279. [CrossRef]

116. de Bang, T.C.; Husted, S.; Laursen, K.H.; Persson, D.P.; Schjoerring, J.K. The molecular-physiological functions of mineral macronutrients and their consequences for deficiency symptoms in plants. New Phytol. 2021, 229, 2446-2469. [CrossRef] [PubMed]

117. Pylak, M.; Oszust, K.; Frąc, M. Review report on the role of bioproducts, biopreparations, biostimulants and microbial inoculants in organic production of fruit. Rev. Environ. Sci. Bio./Technol. 2019, 18, 597-616. [CrossRef]

118. Elena, A.; Diane, L.; Eva, B.; Marta, F.; Roberto, B.; Zamarreño, A.M.; García-Mina, J.M. The root application of a purified leonardite humic acid modifies the transcriptional regulation of the main physiological root responses to Fe deficiency in Fe-sufficient cucumber plants. Plant Physiol. Biochem. 2009, 47, 215-223. [CrossRef]

119. Pacholczak, A.; Nowakowska, K.; Pietkiewicz, S. Physiological aspects in propagation of Ninebark (Physocarpus opulifolius Maxim) by stem cuttings treated with auxin or biostimulator. Not. Bot. Horti Agrobo. 2016, 44, 85-91. [CrossRef]

120. Hernández-Herrera, R.M.; Santacruz-Ruvalcaba, F.; Zañudo-Hernández, J.; Hernández-Carmona, G. Activity of seaweed extracts and polysaccharide-enriched extracts from Ulva lactuca and Padina gymnospora as growth promoters of tomato and mung bean plants. J. Appl. Phycol. 2016, 28, 2549-2560. [CrossRef]

121. Cerdán, M.; Sánchez-Sánchez, A.; Jordá, J.D.; Juárez, M.; Sánchez-Andreu, J. Effect of commercial amino acids on iron nutrition of tomato plants grown under lime-induced iron deficiency. Z. Pflanzenernähr. Bodenk. 2013, 176, 859-866. [CrossRef]

122. Rubin, R.L.; van Groenigen, K.J.; Hungate, B.A. Plant growth promoting rhizobacteria are more effective under drought: A meta-analysis. Plant Soil 2017, 416, 309-323. [CrossRef]

123. Schiavon, M.; Ertani, A.; Nardi, S. Effects of an alfalfa protein hydrolysate on the gene expression and activity of enzymes of the tricarboxylic acid (TCA) cycle and nitrogen metabolism in Zea mays L. J. Agric. Food Chem. 2008, 56, 11800-11808. [CrossRef]

124. Ertani, A.; Cavani, L.; Pizzeghello, D.; Brandellero, E.; Altissimo, A.; Ciavatta, C.; Nardi, S. Biostimulant activity of two protein hydrolyzates in the growth and nitrogen metabolism of maize seedlings. Z. Pflanzenernähr. Bodenk. 2009, 172, 237-244. [CrossRef]

125. Zhang, X.; Wang, K.; Ervin, E.H. Optimizing dosages of seaweed extract-based cytokinins and zeatin riboside for improving creeping bentgrass heat tolerance. Crop Sci. 2010, 50, 316-320. [CrossRef] 
126. Goñi, G.; Łangowski, L.; Feeney, E.; Quille, P.; O'Connell, S. Reducing nitrogen input in barley crops while maintaining yields using an engineered biostimulant derived from Ascophyllum nodosum to enhance nitrogen use efficiency. Front. Plant Sci. 2021, 12, 789. [CrossRef] [PubMed]

127. Durand, N.; Briand, X.; Meyer, C. The effect of marine bioactive substances (N PRO) and exogenous cytokinins on nitrate reductase activity in Arabidopsis thaliana. Physiol Plant 2003, 119, 489-493. [CrossRef]

128. Shukla, P.S.; Mantin, E.G.; Adil, M.; Bajpai, S.; Critchley, A.T.; Prithiviraj, B. Ascophyllum nodosum-based biostimulants: Sustainable applications in agriculture for the stimulation of plant growth, stress tolerance, and disease management. Front. Plant Sci. 2019, 10, 655. [CrossRef] [PubMed]

129. Sadiq, Y.; Zaid, A.; Khan, M.M.A. Adaptive physiological responses of plants under abiotic stresses: Role of phytohormones. In Plant Ecophysiology and Adaptation under Climate Change: Mechanisms and Perspectives I.; Hasanuzzaman, M., Ed.; Springer: Singapore, 2020; pp. 797-824.

130. Hosseinzadeh, S.R.; Amiri, H.; Ismaili, A. Evaluation of photosynthesis, physiological, and biochemical responses of chickpea (Cicer arietinum L. cv. Pirouz) under water deficit stress and use of vermicompost fertilizer. J. Integr. Agric. 2019, 17, $2426-2437$. [CrossRef]

131. Ali, Q.; Shehzad, F.; Waseem, M.; Shahid, S.; Hussain, A.I.; Haider, M.Z.; Habib, N.; Hussain, S.M.; Javed, M.T.; Perveen, R. Plant-based biostimulants and plant stress responses. In Plant Ecophysiology and Adaptation under Climate Change: Mechanisms and Perspectives I.; Hasanuzzaman, M., Ed.; Springer: Singapore, 2020; pp. 625-661.

132. Briglia, N.; Petrozza, A.; Hoeberichts, F.A.; Verhoef, N.; Povero, G. Investigating the impact of biostimulants on the row crops corn and soybean using high-efficiency phenotyping and next generation sequencing. Agronomy 2019, 9, 761. [CrossRef]

133. Soppelsa, S.; Kelderer, M.; Casera, C.; Bassi, M.; Robatscher, P.; Matteazzi, A.; Andreotti, C. Foliar applications of biostimulants promote growth, yield and fruit quality of strawberry plants grown under nutrient limitation. Agronomy 2019, 9, 483. [CrossRef]

134. Carillo, P.; Woo, S.L.; Comite, E.; El-Nakhel, C.; Rouphael, Y.; Fusco, G.M.; Borzacchiello, A.; Lanzuise, S.; Vinale, F. Application of Trichoderma harzianum, 6-pentyl- $\alpha$-pyrone and plant biopolymer formulations modulate plant metabolism and fruit quality of plum tomatoes. Plants 2020, 9, 771. [CrossRef]

135. Giovannini, L.; Palla, M.; Agnolucci, M.; Avio, L.; Sbrana, C.; Turrini, A.; Giovannetti, M. Arbuscular mycorrhizal fungi and associated microbiota as plant biostimulants: Research strategies for the selection of the best performing inocula. Agronomy 2020 10, 106. [CrossRef]

136. Di Mola, I.; Cozzolino, E.; Ottaiano, L.; Nocerino, S.; Rouphael, Y.; Colla, G.; El-Nakhel, C.; Mori, M. Nitrogen use and uptake efficiency and crop performance of baby spinach (Spinacia oleracea L.) and lamb's lettuce (Valerianella locusta L.) grown under variable sub-optimal N regimes combined with plant-based biostimulant application. Agronomy 2020, 10, 278. [CrossRef]

137. Lola-Luz, T.; Hennequart, F.; Gaffney, M. Effect on yield, total phenolic, total flavonoid and total isothiocyanate content of two broccoli cultivars (Brassica oleraceae var Italica) following the application of a commercial brown seaweed extract (Ascophyllum nodosum). AFSci 2014, 23, 28-37. [CrossRef]

138. Sani, M.N.H.; Islam, M.N.; Uddain, J.; Chowdhury, M.S.N.; Subramaniam, S. Synergistic effect of microbial and nonmicrobial biostimulants on growth, yield, and nutritional quality of organic tomato. Crop Sci. 2020, 60, 2102-2114. [CrossRef]

139. Singh, U.B.; Malviya, D.; Khan, W.; Singh, S.; Karthikeyan, N.; Imran, M.; Rai, J.P.; Sarma, B.K.; Manna, M.C.; Chaurasia, R.; et al Earthworm grazed-Trichoderma harzianum biofortified spent mushroom substrates modulate accumulation of natural antioxidants and bio-fortification of mineral nutrients in tomato. Front. Plant Sci. 2018, 9, 1017. [CrossRef]

140. Pichereaux, C.; Laurent, E.-A.; Gargaros, A.; Viudes, S.; Durieu, C.; Lamaze, T.; Grieu, P.; Burlet-Schiltz, O. Analysis of durum wheat proteome changes under marine and fungal biostimulant treatments using large-scale quantitative proteomics: A useful dataset of durum wheat proteins. J. Proteom. 2019, 200, 28-39. [CrossRef]

141. Hernández-Herrera, R.M.; Santacruz-Ruvalcaba, F.; Ruiz-López, M.A.; Norrie, J.; Hernández-Carmona, G. Effect of liquid seaweed extracts on growth of tomato seedlings (Solanum lycopersicum L.). J. Appl. Phycol. 2014, 26, 619-628. [CrossRef]

142. Supraja, K.V.; Behera, B.; Balasubramanian, P. Efficacy of microalgal extracts as biostimulants through seed treatment and foliar spray for tomato cultivation. Ind. Crops Prod. 2020, 151, 112453.

143. Dookie, M.; Ali, O.; Ramsubhag, A.; Jayaraman, J. Flowering gene regulation in tomato plants treated with brown seaweed extracts. Sci. Hortic. 2021, 276, 109715. [CrossRef]

144. Vasantharaja, R.; Abraham, L.S.; Inbakandan, D.; Thirugnanasambandam, R.; Senthilvelan, T.; Jabeen, S.K.A.; Prakash, P. Influence of seaweed extracts on growth, phytochemical contents and antioxidant capacity of cowpea (Vigna unguiculata L. Walp). Biocatal. Agric. Biotechnol. 2019, 17, 589-594. [CrossRef]

145. Mattner, S.W.; Wite, D.; Riches, D.A.; Porter, I.J.; Arioli, T. The effect of kelp extract on seedling establishment of broccoli on contrasting soil types in southern Victoria, Australia. Biol. Agric. Hortic. 2013, 29, 258-270. [CrossRef]

146. Flores, P.; Pedreño, M.A.; Almagro, L.; Hernández, V.; Fenoll, J.; Hellín, P. Increasing nutritional value of broccoli with seaweed extract and trilinolein. J. Food Compos. Anal. 2021, 98, 103834. [CrossRef]

147. Ahmed, Y.M.; Shalaby, E.A. Effect of different seaweed extracts and compost on vegetative growth, yield and fruit quality of cucumber. J. Hortic. Sci. Ornam. Plants 2012, 4, 235-240.

148. Manna, D.; Sarkar, A.; Maity, T.K. Impact of biozyme on growth, yield and quality of chilli (Capsicum annuum L.). J. Crop Weed $2012,8,40-43$ 
149. Kulkarni, M.G.; Rengasamy, K.R.R.; Pendota, S.C.; Gruz, J.; Plačková, L.; Novák, O.; Doležal, K.; van Staden, J. Bioactive molecules derived from smoke and seaweed Ecklonia maxima showing phytohormone-like activity in Spinacia oleracea L. New Biotechnol. 2019, 48, 83-89. [CrossRef]

150. Mattarozzi, M.; Di Zinno, J.; Montanini, B.; Manfredi, M.; Marengo, E.; Fornasier, F.; Ferrarini, A.; Careri, M.; Visioli, G. Biostimulants applied to maize seeds modulate the enzymatic activity and metaproteome of the rhizosphere. Appl. Soil Ecol. 2020, 148, 103480. [CrossRef]

151. Weber, N.; Schmitzer, V.; Jakopic, J.; Stampar, F. First fruit in season: Seaweed extract and silicon advance organic strawberry (Fragaria $\times$ ananassa Duch.) fruit formation and yield. Sci. Hortic. 2018, 242, 103-109. [CrossRef]

152. Kocira, A.; Świeca, M.; Kocira, S.; Złotek, U.; Jakubczyk, A. Enhancement of yield, nutritional and nutraceutical properties of two common bean cultivars following the application of seaweed extract (Ecklonia maxima). Saudi J. Biol. Sci. 2018, $25,563-571$. [CrossRef]

153. Kocira, S.; Szparaga, A.; Hara, P.; Treder, K.; Findura, P.; Bartoš, P.; Filip, M. Biochemical and economical effect of application biostimulants containing seaweed extracts and amino acids as an element of agroecological management of bean cultivation. Sci. Rep. 2020, 10, 17759. [CrossRef]

154. Ertani, A.; Pizzeghello, D.; Baglieri, A.; Cadili, V.; Tambone, F.; Gennari, M.; Nardi, S. Humic-like substances from agro-industrial residues affect growth and nitrogen assimilation in maize (Zea mays L.) plantlets. J. Geochem. Explor. 2013, 129, 103-111. [CrossRef]

155. Zanin, L.; Tomasi, N.; Zamboni, A.; Sega, D.; Varanini, Z.; Pinton, R. Water-extractable humic substances speed up transcriptional response of maize roots to nitrate. Environ. Exp. Bot. 2018, 147, 167-178. [CrossRef]

156. Bettoni, M.M.; Mogor, Á.F.; Pauletti, V.; Goicoechea, N.; Aranjuelo, I.; Garmendia, I. Nutritional quality and yield of onion as affected by different application methods and doses of humic substances. J. Food Compos. Anal. 2016, 51, 37-44. [CrossRef]

157. Abbas, M.; Anwar, J.; Zafar-ul-Hye, M.; Iqbal Khan, R.; Saleem, M.; Rahi, A.A.; Danish, S.; Datta, R. Effect of seaweed extract on productivity and quality attributes of four onion cultivars. Horticulturae 2020, 6, 28. [CrossRef]

158. Aghaeifard, F.; Babalar, M.; Fallahi, E.; Ahmadi, A. Influence of humic acid and salicylic acid on yield, fruit quality, and leaf mineral elements of strawberry (Fragaria $\times$ Ananassa duch) cv. Camarosa. J. Plant Nutr. 2016, 39, 1821-1829. [CrossRef]

159. Machiani, M.A.; Rezaei-Chiyaneh, E.; Javanmard, A.; Maggi, F.; Morshedloo, M.R. Evaluation of common bean (Phaseolus vulgaris L.) seed yield and quali-quantitative production of the essential oils from fennel (Foeniculum vulgare Mill.) and dragonhead (Dracocephalum moldavica L.) in intercropping system under humic acid application. J. Clean. Prod. 2019, 235, 112-122. [CrossRef]

160. Dehsheikh, A.B.; Sourestani, M.M.; Zolfaghari, M.; Enayatizamir, N. Changes in soil microbial activity, essential oil quantity, and quality of Thai basil as response to biofertilizers and humic acid. J. Clean. Prod. 2020, 256, 120439. [CrossRef]

161. Roomi, S.; Masi, A.; Conselvan, G.B.; Trevisan, S.; Quaggiotti, S.; Pivato, M.; Arrigoni, G.; Yasmin, T.; Carletti, P. Protein profiling of Arabidopsis roots treated with humic substances: Insights into the metabolic and interactome networks. Front. Plant Sci. 2018, 9, 1812. [CrossRef] [PubMed]

162. Sestili, F.; Rouphael, Y.; Cardarelli, M.; Pucci, A.; Bonini, P.; Canaguier, R.; Colla, G. Protein hydrolysate stimulates growth in tomato coupled with N-dependent gene expression involved in N assimilation. Front. Plant Sci. 2018, 9, 1233. [CrossRef] [PubMed]

163. Tejada, M.; Rodríguez-Morgado, B.; Paneque, P.; Parrado, J. Effects of foliar fertilization of a biostimulant obtained from chicken feathers on maize yield. Eur. J. Agron. 2018, 96, 54-59. [CrossRef]

164. Ertani, A.; Nardi, S.; Francioso, O.; Sanchez-Cortes, S.; Foggia, M.D.; Schiavon, M. Effects of two protein hydrolysates obtained from chickpea (Cicer arietinum L.) and Spirulina platensis on Zea mays (L.) plants. Front. Plant Sci. 2019, 10, 954. [CrossRef]

165. Santi, C.; Zamboni, A.; Varanini, Z.; Pandolfini, T. Growth stimulatory effects and genome-wide transcriptional changes produced by protein hydrolysates in maize seedlings. Front. Plant Sci. 2017, 8, 433. [CrossRef]

166. González-González, M.F.; Ocampo-Alvarez, H.; Santacruz-Ruvalcaba, F.; Sánchez-Hernández, C.V.; Casarrubias-Castillo, K.; Becerril-Espinosa, A.; Castañeda-Nava, J.J.; Hernández-Herrera, R.M. Physiological, ecological, and biochemical implications in tomato plants of two plant biostimulants: Arbuscular mycorrhizal fungi and seaweed extract. Front. Plant Sci. 2020, 11, 999. [CrossRef]

167. Song, Z.; Bi, Y.; Zhang, J.; Gong, Y.; Yang, H. Arbuscular mycorrhizal fungi promote the growth of plants in the mining associated clay. Sci. Rep. 2020, 10, 2663. [CrossRef]

168. Visconti, D.; Fiorentino, N.; Cozzolino, E.; Woo, S.L.; Fagnano, M.; Rouphael, Y. Can Trichoderma-based biostimulants optimize $\mathrm{N}$ use efficiency and stimulate growth of leafy vegetables in greenhouse intensive cropping systems? Agronomy 2020, 10, 121. [CrossRef]

169. Kalam, S.; Basu, A.; Podile, A.R. Functional and molecular characterization of plant growth promoting Bacillus isolates from tomato rhizosphere. Heliyon 2020, 6, e04734. [CrossRef] [PubMed]

170. Agarwal, P.; Singh, P.C.; Chaudhry, V.; Shirke, P.A.; Chakrabarty, D.; Farooqui, A.; Nautiyal, C.S.; Sane, A.P.; Sane, V.A. PGPRinduced OsASR6 improves plant growth and yield by altering root auxin sensitivity and the xylem structure in transgenic Arabidopsis thaliana. J. Plant Physiol. 2019, 240, 153010. [CrossRef] [PubMed]

171. Dal Cortivo, C.; Barion, G.; Visioli, G.; Mattarozzi, M.; Mosca, G.; Vamerali, T. Increased root growth and nitrogen accumulation in common wheat following PGPR inoculation: Assessment of plant-microbe interactions by ESEM. Agric. Ecosyst. Environ. 2017, 247, 396-408. [CrossRef] 
172. Ureche, M.A.L.; Pérez-Rodriguez, M.M.; Ortiz, R.; Monasterio, R.P.; Cohen, A.C. Rhizobacteria improve the germination and modify the phenolic compound profile of pepper (Capsicum annum L.). Rhizosphere 2021, 18, 100334. [CrossRef]

173. Ejaz, S.; Batool, S.; Anjum, M.A.; Naz, S.; Qayyum, M.F.; Naqqash, T.; Shah, K.H.; Ali, S. Effects of inoculation of root associative Azospirillum and Agrobacterium strains on growth, yield and quality of pea (Pisum sativum L.) grown under different nitrogen and phosphorus regimes. Sci. Hortic. 2020, 270, 109401. [CrossRef]

174. Wang, W.; Vinocur, B.; Altman, A. Plant responses to drought, salinity and extreme temperatures: Towards genetic engineering for stress tolerance. Planta 2003, 218, 1-14. [CrossRef]

175. van Oosten, M.J.; Pepe, O.; De Pascale, S.; Silletti, S.; Maggio, A. The role of biostimulants and bioeffectors as alleviators of abiotic stress in crop plants. Chem. Biol. Technol. Agric. 2017, 4, 1-12. [CrossRef]

176. Drobek, M.; Frac, M.; Cybulska, J. Plant biostimulants: Importance of the quality and yield of horticultural crops and the improvement of plant tolerance to abiotic stress-A review. Agronomy 2019, 9, 335. [CrossRef]

177. Chaudhary, D.; Narula, N.; Sindhu, S.S.; Behl, R.K. Plant growth stimulation of wheat (Triticum aestivum L.) by inoculation of salinity tolerant Azotobacter strains. Physiol. Mol. Biol. Plants 2013, 19, 515-519. [CrossRef]

178. Ali, S.Z.; Sandhya, V.; Grover, M.; Linga, V.R.; Bandi, V. Effect of inoculation with a thermotolerant plant growth promoting Pseudomonas putida strain AKMP7 on growth of wheat (Triticum spp.) under heat stress. J. Plant Interact. 2011, 6, 239-246. [CrossRef]

179. Selvakumar, G.; Kundu, S.; Joshi, P.; Nazim, S.; Gupta, A.D.; Mishra, P.K.; Gupta, H.S. Characterization of a cold-tolerant plant growth-promoting bacterium Pantoea dispersa 1A isolated from a sub-alpine soil in the north western Indian Himalayas. World J. Microbiol. Biotechnol. 2008, 24, 955-960. [CrossRef]

180. Theocharis, A.; Bordiec, S.; Fernandez, O.; Paquis, S.; Dhondt-Cordelier, S.; Baillieul, F.; Clément, C.; Barka, E.A. Burkholderia phytofirmans PsJN primes Vitis vinifera L. and confers a better tolerance to low nonfreezing temperatures. MPMI 2012, 25, 241-249. [CrossRef]

181. Nadeem, S.M.; Zahir, Z.A.; Naveed, M.; Ashraf, M. Microbial ACC-deaminase: Prospects and applications for inducing salt tolerance in plants. Crit. Rev. Plant Sci. 2010, 29, 360-393. [CrossRef]

182. Bradáčová, K.; Weber, N.F.; Morad-Talab, N.; Asim, M.; Imran, M.; Weinmann, M.; Neumann, G. Micronutrients (Zn/Mn), seaweed extracts, and plant growth-promoting bacteria as cold-stress protectants in maize. Chem. Biol. Technol. Agric. 2016, 3, 1-10. [CrossRef]

183. Zhang, X.; Ervin, E.H. Impact of seaweed extract-based cytokinins and zeatin riboside on creeping bentgrass heat tolerance. Crop Sci. 2008, 48, 364-370. [CrossRef]

184. Ertani, A.; Schiavon, M.; Muscolo, A.; Nardi, S. Alfalfa plant-derived biostimulant stimulate short-term growth of salt stressed Zea mays L. plants. Plant Soil 2013, 364, 145-158. [CrossRef]

185. De Vleesschauwer, D.; Höfte, M. Rhizobacteria-induced systemic resistance. In Advances in Botanical Research; Elsevier: Amsterdam, The Netherlands, 2009; Volume 51, pp. 223-281.

186. Kloepper, J.W.; Ryu, C.-M.; Zhang, S. Induced systemic resistance and promotion of plant growth by Bacillus spp. Phytopathology 2004, 94, 1259-1266. [CrossRef] [PubMed]

187. Bakker, P.A.H.M.; Pieterse, C.M.J.; van Loon, L.C. Induced systemic resistance by fluorescent Pseudomonas spp. Phytopathology 2007, 97, 239-243. [CrossRef]

188. Fraceto, L.F.; Maruyama, C.R.; Guilger, M.; Mishra, S.; Keswani, C.; Singh, H.B.; de Lima, R. Trichoderma harzianum-based novel formulations: Potential applications for management of Next-Gen agricultural challenges. J. Chem. Technol. Biotechnol. 2018, 93, 2056-2063. [CrossRef]

189. Glick, B.R. Bacteria with ACC deaminase can promote plant growth and help to feed the world. Microbiol. Res. 2014, 169, 30-39. [CrossRef] [PubMed]

190. Cheng, Z.; Park, E.; Glick, B.R. 1-Aminocyclopropane-1-carboxylate deaminase from Pseudomonas putida UW4 facilitates the growth of canola in the presence of salt. Can. J. Microbiol. 2007, 53, 912-918. [CrossRef] [PubMed]

191. Barsanti, L.; Coltelli, P.; Gualtieri, P. Paramylon treatment improves quality profile and drought resistance in Solanum lycopersicum L. cv. Micro-Tom. Agronomy 2019, 9, 394. [CrossRef]

192. Casadesús, A.; Polo, J.; Munné-Bosch, S. Hormonal effects of an enzymatically hydrolyzed animal protein-based biostimulant (Pepton) in water-stressed tomato plants. Front. Plant Sci. 2019, 10, 758. [CrossRef]

193. do Rosário Rosa, V.; Farias dos Santos, A.L.; Alves da Silva, A.; Peduti Vicentini Sab, M.; Germino, G.H.; Barcellos Cardoso, F.; de Almeida Silva, M. Increased soybean tolerance to water deficiency through biostimulant based on fulvic acids and Ascophyllum nodosum (L.) seaweed extract. Plant Physiol. Biochem. 2021, 158, 228-243. [CrossRef] [PubMed]

194. Rayirath, P.; Benkel, B.; Hodges, D.M.; Allan-Wojtas, P.; MacKinnon, S.; Critchley, A.T.; Prithiviraj, B. Lipophilic components of the brown seaweed, Ascophyllum nodosum, enhance freezing tolerance in Arabidopsis thaliana. Planta 2009, 230, 135-147. [CrossRef]

195. Sharma, S.; Chen, C.; Khatri, K.; Rathore, M.S.; Pandey, S.P. Gracilaria dura extract confers drought tolerance in wheat by modulating abscisic acid homeostasis. Plant Physiol. Biochem. 2019, 136, 143-154. [CrossRef] [PubMed]

196. Xu, C.; Leskovar, D.I. Effects of A. nodosum seaweed extracts on spinach growth, physiology and nutrition value under drought stress. Sci. Hortic. 2015, 183, 39-47. [CrossRef] 
197. Santaniello, A.; Scartazza, A.; Gresta, F.; Loreti, E.; Biasone, A.; Di Tommaso, D.; Piaggesi, A.; Perata, P. Ascophyllum nodosum seaweed extract alleviates drought stress in Arabidopsis by affecting photosynthetic performance and related gene expression. Front. Plant Sci. 2017, 8, 1362. [CrossRef] [PubMed]

198. Jithesh, M.N.; Shukla, P.S.; Kant, P.; Joshi, J.; Critchley, A.T.; Prithiviraj, B. Physiological and transcriptomics analyses reveal that Ascophyllum nodosum extracts induce salinity tolerance in Arabidopsis by regulating the expression of stress responsive genes. J. Plant Growth Regul. 2019, 38, 463-478. [CrossRef]

199. Carmody, N.; Goñi, O.; Łangowski, Ł.; O'Connell, S. Ascophyllum nodosum extract biostimulant processing and its impact on enhancing heat stress tolerance during tomato fruit set. Front. Plant Sci. 2020, 11, 807. [CrossRef]

200. Kaluzewicz, A.; Bosiacki, M.; Spizewski, T. Influence of biostimulants on the content of macro-and micronutrients in broccoli plants exposed to drought stress. J. Elem. 2018, 23, 287-297.

201. Yang, M.; Lei, Z.; Xu, T.; McLaughlin, N.B.; Liu, J. Effect of water-soluble humic acid applied to potato foliage on plant growth, photosynthesis characteristics and fresh tuber yield under different water deficits. Sci. Rep. 2020, 10, 7854.

202. Ozfidan-Konakci, C.; Yildiztugay, E.; Bahtiyar, M.; Kucukoduk, M. The humic acid-induced changes in the water status, chlorophyll fluorescence and antioxidant defense systems of wheat leaves with cadmium stress. Ecotoxicol. Environ. Saf. 2018, 155, 66-75. [CrossRef]

203. Saidimoradi, D.; Ghaderi, N.; Javadi, T. Salinity stress mitigation by humic acid application in strawberry (Fragaria $\mathrm{x}$ ananassa Duch.). Sci. Hortic. 2019, 256, 108594. [CrossRef]

204. Lotfi, R.; Kalaji, H.M.; Valizadeh, G.R.; Behrozyar, E.; Hemati, A.; Gharavi-Kochebagh, P.; Ghassemi, A. Effects of humic acid on photosynthetic efficiency of rapeseed plants growing under different watering conditions. Photosynthetica 2018, 56, 962-970. [CrossRef]

205. Sitohy, M.Z.; Desoky, E.-S.M.; Osman, A.; Rady, M.M. Pumpkin seed protein hydrolysate treatment alleviates salt stress effects on Phaseolus vulgaris by elevating antioxidant capacity and recovering ion homeostasis. Sci. Hortic. 2020, 271, 109495. [CrossRef]

206. Boselli, M.; Bahouaoui, M.A.; Lachhab, N.; Sanzani, S.M.; Ferrara, G.; Ippolito, A. Protein hydrolysates effects on grapevine (Vitis vinifera L., cv. Corvina) performance and water stress tolerance. Sci. Hortic. 2019, 258, 108784. [CrossRef]

207. Di Mola, I.; Cozzolino, E.; Ottaiano, L.; Giordano, M.; Rouphael, Y.; Colla, G.; Mori, M. Effect of vegetal- and seaweed Extractbased biostimulants on agronomical and leaf quality traits of plastic tunnel-grown baby lettuce under four regimes of nitrogen fertilization. Agronomy 2019, 9, 571. [CrossRef]

208. Di Mola, I.; Ottaiano, L.; Cozzolino, E.; Senatore, M.; Giordano, M.; El-Nakhel, C.; Sacco, A.; Rouphael, Y.; Colla, G.; Mori, M. Plant-based biostimulants influence the agronomical, physiological, and qualitative responses of baby rocket leaves under diverse nitrogen conditions. Plants 2019, 8, 522. [CrossRef]

209. Dehkordi, R.A.; Roghani, S.R.; Mafakheri, S.; Asghari, B. Effect of biostimulants on morpho-physiological traits of various ecotypes of fenugreek (Trigonella foenum-graecum L.) under water deficit stress. Sci. Hortic. 2021, 283, 110077. [CrossRef]

210. Eroğlu, Ç.G.; Cabral, C.; Ravnskov, S.; Bak Topbjerg, H.; Wollenweber, B. Arbuscular mycorrhiza influences carbon-use efficiency and grain yield of wheat grown under pre- and post-anthesis salinity stress. Plant Biol. J. 2020, 22, 863-871. [CrossRef] [PubMed]

211. Elhindi, K.M.; El-Din, A.S.; Elgorban, A.M. The impact of arbuscular mycorrhizal fungi in mitigating salt-induced adverse effects in sweet basil (Ocimum basilicum L.). Saudi J. Biol. Sci. 2017, 24, 170-179. [CrossRef]

212. Begum, N.; Ahanger, M.A.; Su, Y.; Lei, Y.; Mustafa, N.S.A.; Ahmad, P.; Zhang, L. Improved drought tolerance by AMF inoculation in maize (Zea mays) involves physiological and biochemical implications. Plants 2019, 8, 579. [CrossRef] [PubMed]

213. Adeyemi, N.O.; Atayese, M.O.; Sakariyawo, O.S.; Azeez, J.O.; Abayomi Sobowale, S.P.; Olubode, A.; Mudathir, R.; Adebayo, R.; Adeoye, S. Alleviation of heavy metal stress by arbuscular mycorrhizal symbiosis in Glycine max (L.) grown in copper, lead and zinc contaminated soils. Rhizosphere 2021, 18, 100325. [CrossRef]

214. Rahimi, S.; Talebi, M.; Baninasab, B.; Gholami, M.; Zarei, M.; Shariatmadari, H. The role of plant growth-promoting rhizobacteria (PGPR) in improving iron acquisition by altering physiological and molecular responses in quince seedlings. Plant Physiol. Biochem. 2020, 155, 406-415. [CrossRef]

215. Pereira, S.I.A.; Abreu, D.; Moreira, H.; Vega, A.; Castro, P.M.L. Plant growth-promoting rhizobacteria (PGPR) improve the growth and nutrient use efficiency in maize (Zea mays L.) under water deficit conditions. Heliyon 2020, 6, e05106. [CrossRef]

216. Khanna, K.; Jamwal, V.L.; Sharma, A.; Gandhi, S.G.; Ohri, P.; Bhardwaj, R.; Al-Huqail, A.A.; Siddiqui, M.H.; Ali, H.M.; Ahmad, P. Supplementation with plant growth promoting rhizobacteria (PGPR) alleviates cadmium toxicity in Solanum lycopersicum by modulating the expression of secondary metabolites. Chemosphere 2019, 230, 628-639. [CrossRef]

217. Brunetti, C.; Saleem, A.R.; Della Rocca, G.; Emiliani, G.; De Carlo, A.; Balestrini, R.; Khalid, A.; Mahmood, T.; Centritto, M. Effects of plant growth-promoting rhizobacteria strains producing ACC deaminase on photosynthesis, isoprene emission, ethylene formation and growth of Mucuna pruriens (L.) DC. in response to water deficit. J. Biotechnol. 2021, 331, 53-62. [CrossRef] [PubMed]

218. Babar, M.; Rasul, S.; Aslam, K.; Abbas, R.; Manzoor, I.; Hanif, M.K.; Naqqash, T. Mining of halo-tolerant plant growth promoting rhizobacteria and their impact on wheat (Triticum aestivum L.) under saline conditions. J. King Saud Univ-Sci. 2021, 33, 101372. [CrossRef]

219. Rabiei, Z.; Hosseini, S.J.; Pirdashti, H.; Hazrati, S. Physiological and biochemical traits in coriander affected by plant growthpromoting rhizobacteria under salt stress. Heliyon 2020, 6, e05321. [CrossRef] 
220. Yasmeen, T.; Ahmad, A.; Arif, M.S.; Mubin, M.; Rehman, K.; Shahzad, S.M.; Iqbal, S.; Rizwan, M.; Ali, S.; Alyemeni, M.N.; et al. Biofilm forming rhizobacteria enhance growth and salt tolerance in sunflower plants by stimulating antioxidant enzymes activity. Plant Physiol. Biochem. 2020, 156, 242-256. [CrossRef] [PubMed]

221. Abbasi, S.; Sadeghi, A.; Safaie, N. Streptomyces alleviate drought stress in tomato plants and modulate the expression of transcription factors ERF1 and WRKY70 genes. Sci. Hortic. 2020, 265, 109206. [CrossRef]

222. Baldotto, L.E.B.; Baldotto, M.A.; Canellas, L.P.; Bressan-Smith, R.; Olivares, F.L. Growth promotion of pineapple "vitória" by humic acids and Burkholderia spp. during acclimatization. Rev. Bras. Ciênc. Solo 2010, 34, 1593-1600. [CrossRef]

223. Bettoni, M.M.; Mogor, Á.F.; Pauletti, V.; Goicoechea, N. Growth and metabolism of onion seedlings as affected by the application of humic substances, mycorrhizal inoculation and elevated $\mathrm{CO}_{2}$. Sci. Hortic. 2014, 180, 227-235. [CrossRef]

224. Nikbakht, A.; Pessarakli, M.; Daneshvar-Hakimi-Maibodi, N.; Kafi, M. Perennial ryegrass growth responses to mycorrhizal infection and humic acid treatments. Agron. J. 2014, 106, 585-595. [CrossRef]

225. Prakash, P.; Medhi, S.; Saikia, S.; Narendrakumar, G.; Thirugnanasambandam, T.; Abraham, L.S. Production, formulation and application of seaweed liquid fertilizer using humic acid on growth of Arachis hypogaea. Biosci. Biotechnol. Res. Asia 2014, 11, 1515-1519. [CrossRef]

226. Rouphael, Y.; Carillo, P.; Colla, G.; Fiorentino, N.; Sabatino, L.; El-Nakhel, C.; Giordano, M.; Pannico, A.; Cirillo, V.; Shabani, E.; et al. Appraisal of combined applications of Trichoderma virens and a biopolymer-based biostimulant on lettuce agronomical, physiological, and qualitative properties under variable N regimes. Agronomy 2020, 10, 196. [CrossRef]

227. Anli, M.; Kaoua, M.E.; ait-el-Mokhtar, M.; Boutasknit, A.; ben-Laouane, R.; Toubali, S.; Baslam, M.; Lyamlouli, K.; Hafidi, M.; Meddich, A. Seaweed extract application and arbuscular mycorrhizal fungal inoculation: A tool for promoting growth and development of date palm (Phoenix dactylifera L.) cv “Boufgous". S. Afr. J. Bot. 2020, 132, 15-21. [CrossRef]

228. Djouhou, F.M.C.; Nwaga, D.; Fokou, E. Comparative effect of arbuscular mycorrhizal fungi and biostimulants on the antioxidant and nutritional potential of Moringa oleifera. Nutr. Food Sci. Int. J. 2019, 9, 555757.

229. Caruso, G.; El-Nakhel, C.; Rouphael, Y.; Comite, E.; Lombardi, N.; Cuciniello, A.; Woo, S.L. Diplotaxis tenuifolia (L.) DC. yield and quality as influenced by cropping season, protein hydrolysates, and Trichoderma applications. Plants 2020, 9, 697. [CrossRef] [PubMed]

230. Giordano, M.; El-Nakhel, C.; Caruso, G.; Cozzolino, E.; De Pascale, S.; Kyriacou, M.C.; Colla, G.; Rouphael, Y. Stand-alone and combinatorial effects of plant-based biostimulants on the production and leaf quality of perennial wall rocket. Plants 2020, 9, 922 [CrossRef]

231. Ngoroyemoto, N.; Kulkarni, M.G.; Stirk, W.A.; Gupta, S.; Finnie, J.F.; van Staden, J. Interactions between microorganisms and a seaweed-derived biostimulant on the growth and biochemical composition of Amaranthus hybridus L. Nat. Prod. Commun. 2020, $15,1-11$.

232. Torun, H.; Toprak, B. Arbuscular mycorrhizal fungi and K-humate combined as biostimulants: Changes in antioxidant defense system and radical scavenging capacity in Elaeagnus angustifolia. J. Soil Sci. Plant Nutr. 2020, 20, 2379-2393. [CrossRef]

233. Allaga, H.; Bóka, B.; Poór, P.; Nagy, V.D.; Szúcs, A.; Stankovics, I.; Takó, M.; Manczinger, L.; Vágvölgyi, C.; Kredics, L.; et al. A composite bioinoculant based on the combined application of beneficial bacteria and fungi. Agronomy 2020, 10, 220. [CrossRef]

234. Vimal, S.R.; Singh, J.S.; Arora, N.K.; Singh, S. Soil-plant-microbe interactions in stressed agriculture management: A review. Pedosphere 2017, 27, 177-192. [CrossRef]

235. French, E.; Kaplan, I.; Iyer-Pascuzzi, A.; Nakatsu, C.H.; Enders, L. Emerging strategies for precision microbiome management in diverse agroecosystems. Nat. Plants 2021, 7, 256-267. [CrossRef]

236. Mohanram, S.; Kumar, P. Rhizosphere microbiome: Revisiting the synergy of plant-microbe interactions. Ann. Microbiol. 2019, 69, 307-320. [CrossRef]

237. Copeland, J.K.; Yuan, L.; Layeghifard, M.; Wang, P.W.; Guttman, D.S. Seasonal community succession of the phyllosphere microbiome. MPMI 2015, 28, 274-285. [CrossRef] [PubMed]

238. Bouskill, N.J.; Wood, T.E.; Baran, R.; Ye, Z.; Bowen, B.P.; Lim, H.; Zhou, J.; Nostrand, J.D.V.; Nico, P.; Northen, T.R.; et al Belowground response to drought in a tropical forest soil. I. Changes in microbial functional potential and metabolism. Front. Microbiol. 2016, 7, 525. [CrossRef]

239. Wong, W.S.; Morald, T.K.; Whiteley, A.S.; Nevill, P.G.; Trengove, R.D.; Yong, J.W.H.; Dixon, K.W.; Valliere, J.M.; Stevens, J.C.; Veneklaas, E.J. Microbial inoculation to improve plant performance in mine waste substrates-A test using pigeon pea (Cajanus cajan). Land Degrad. Dev. 2022, 33. [CrossRef]

240. Yong, J.W.H.; Letham, D.S.; Wong, S.C.; Farquhar, G.D. Rhizobium-induced elevation in xylem cytokinin delivery in pigeonpea induces changes in shoot development and leaf physiology. Funct. Plant Biol. 2014, 41, 1323-1335. [CrossRef] [PubMed] 